\title{
Educators of Prospective Teachers Hesitate to Embrace Evolution Due to Deficient Understanding of Science/Evolution and High Religiosity
}

\author{
Guillermo Paz-y-Miño-C • Avelina Espinosa
}

Published online: 6 March 2012

(C) Springer Science+Business Media, LLC 2012

\begin{abstract}
Acceptance of evolution by educators of prospective teachers remains superficially studied despite their role in having mentored schoolteachers whose weak support of evolution is known. Here, we contrast the views of New England educators of prospective teachers $(n=62 ; 87 \% \mathrm{Ph}$. D./doctorate holders in 32 specializations) with those of the general faculty $(n=244 ; 93 \%$ Ph.D./doctorate holders in 40 disciplines), both members of 35 colleges and universities, and with college students $(n=827$; subsample of the 35 institutions) who were polled on: (1) the controversy evolution vs. creationism vs. intelligent design (ID), (2) their understanding of how science/evolution works, and (3) their religiosity. The educators held intermediate positions in respect to the general faculty and the students: $94 \%$ of the general faculty, $75 \%$ of the educators, and $63 \%$ of the students said they accepted evolution openly; and $82 \%$ of the general faculty, $71 \%$ of the educators, and $58 \%$ of the students thought that evolution is definitely true. Only $3 \%$ of the general faculty in comparison to $19 \%$ of the educators and $24 \%$ of the students thought that evolution and creationism are in harmony. Although $93 \%$ of the general faculty, educators, and students knew that evolution relies on common ancestry, $26 \%$ of the general faculty, $45 \%$ of the
\end{abstract}

Electronic supplementary material The online version of this article (doi:10.1007/s12052-011-0383-9) contains supplementary material, which is available to authorized users.

G. Paz-y-Miño-C

Department of Biology, University of Massachusetts Dartmouth, 285 Old Westport Road,

North Dartmouth, MA 02747-2300, USA

\section{A. Espinosa $(\square)$}

Department of Biology, Roger Williams University,

One Old Ferry Road,

Bristol, RI 02809, USA

e-mail: aespinosa@rwu.edu educators, and $35 \%$ of the students did not know that humans are apes. Remarkably, $15 \%$ of the general faculty, $32 \%$ of the educators, and $35 \%$ of the students believed, incorrectly, that the origin of the human mind cannot be explained by evolution; and $30 \%$ of the general faculty, $59 \%$ of the educators, and $75 \%$ of the students were Lamarckian (=believed in inheritance of acquired traits). For science education: $96 \%$ of the general faculty, $86 \%$ of the educators, and $71 \%$ of the students supported the exclusive teaching of evolution, while $4 \%$ of the general faculty, $14 \%$ of the educators, and $29 \%$ of the students favored equal time to evolution, creationism and ID; note that $92 \%$ of the general faculty, $82 \%$ of the educators, and $50 \%$ of the students perceived ID as either not scientific and proposed to counter evolution based on false claims or as religious doctrine consistent with creationism. The general faculty was the most knowledgeable about science/evolution and the least religious (science index, $\mathrm{SI}=2.49$; evolution index, $\mathrm{EI}=$ 2.49; and religiosity index, $\mathrm{RI}=0.49$ ); the educators reached lower science/evolution but higher religiosity indexes than the general faculty $(\mathrm{SI}=1.96, \mathrm{EI}=1.96$, and $\mathrm{RI}=0.83)$; and the students were the least knowledgeable about science/ evolution and the most religious $(\mathrm{SI}=1.80, \mathrm{EI}=1.60$, and $\mathrm{RI}=0.89$ ). Understanding of science and evolution were inversely correlated with level of religiosity, and understanding of evolution increased with increasing science literacy. Interestingly, $\approx 36 \%$ of the general faculty, educators and students considered religion to be very important in their lives, and $17 \%$ of the general faculty, $34 \%$ of the educators, and $28 \%$ of the students said they prayed daily. Assessing the perception of evolution by educators of prospective teachers vs. the general faculty and the students of New England, one of the historically most progressive regions in the U.S., is crucial for determining the magnitude of the impact of creationism and 
ID on attitudes toward science, reason, and education in science.

Keywords Antievolution wars - College education . Controversy science versus popular belief . Evolution literacy $\cdot$ Evolution polls

\section{Introduction}

Creationism and intelligent design (ID) split the public's support of evolution in the U.S. (Padian 2009; Padian and Matzke 2009; Forrest 2010; Matzke 2010; Paz-y-Miño-C and Espinosa 2011a), where only 40\% of adults accept the concept of evolution (Miller et al. 2006; The Gallup Poll 2009). The U.S. ranks 33rd among 34 other industrialized countries where acceptance of evolution has been polled, in contrast to Iceland, Denmark, Sweden, France, Japan, and the UK, top in the list, where $\approx 75-85 \%$ of the general public accepts evolution (Miller et al. 2006). In the intellectually progressive Northeastern U.S., favorable views toward evolution are the highest nationwide, only 59\% (The Pew Research Center for the People \& the Press 2005).

The concept of evolution provides naturalistic explanations about the origin of life, its diversification and biogeography, and the synergistic phenomena resulting from the interaction between life and the environment (Paz-y-Miño-C and Espinosa 2011b); mutations, gene flow, genetic drift, and natural selection shape life's biological processes in Earth's ecosystems (Mayr 2001). Since the publication of The Origin of Species by Charles Darwin, in 1859, Darwinian evolution has been scrutinized experimentally; today the theory of evolution is widely accepted by the scientific community (Coyne 2009; Dawkins 2009; Paz-y-Miño-C and Espinosa 2011a, b). In contrast, creationism, theistic evolution, creation science, or young Earth creationism (Petto and Godfrey 2007; Matzke 2010; Phy-Olsen 2010) rely on supernatural causation to explain the origin of the universe and life. These views are not recognized by scientists as evidence-based explanations of empirical reality (Padian 2009; Scott 2009; Paz-y-Miño-C and Espinosa 2009a, b, 2011a, b), or of cosmic processes which, according to modern understanding of "cosmic evolution," do encompass the formation of the universe, the emergence of the simplest elements that transformed into more complex elements and molecules, including prebiotic compounds in our planet and that ultimately led to the evolution of molecular diversity and complexity of today's living organisms and ecosystems (see Zaikowski et al. 2008; Krauss 2010; Paz-yMiño-C and Espinosa 2011b).

The doctrine of ID, born in the 1980s, proposes that a designer is responsible, ultimately, for the assemblage of complexity in biological systems; according to ID, evolution cannot explain holistically the origin of the natural world, nor the emergence of intricate molecular pathways essential to life, nor the immense phylogenetic differentiation of life; instead, ID proposes an intelligent agent as the ultimate cause of nature (Pennock 2001; Young and Edis 2004; Forrest and Gross 2007a, b; Miller 2007, 2008; Petto and Godfrey 2007; Phy-Olsen 2010). In conceptually mistaken, type-I-error-based arguments to discredit evolution, ID has attributed randomness to molecular change, deleterious nature to single-gene mutations, insufficient geological time or population size for molecular improvements to occur, and invoked "design intervention" to account for complexity in molecular structures and biological processes (Paz-y-MiñoC and Espinosa 2010; Paz-y-Miño-C et al. 2011). In 2005, ID was exposed in court (Dover, Pennsylvania, Kitzmiller et al. versus Dover School District et al. 2005; Padian and Matzke 2009; Wexler 2010) for violating the rules of science by "invoking and permitting supernatural causation" in matters of evolution, and for "failing to gain acceptance in the scientific community." Today, "design creationism" (as we refer to ID due to its designer/creator-based foundations; Pennock 2001; Paz-y-Miño-C and Espinosa 2010, 2011b; Paz-y-Miño-C et al. 2011) although defeated by science and in the courts, grows influential in the U.S., Europe, Australia and South America (Cornish-Bowden and Cárdenas 2007; Padian 2009; Branch et al. 2010; Forrest 2010; Matzke 2010; Wexler 2010).

Acceptance of evolution among the general public, high school students and teachers, college students, university professors, and scientists has been documented (Bishop and Anderson 1990; Downie and Barron 2000; Moore and Kraemer 2005; Miller et al. 2006; Donnelly and Boone 2007; Moore 2007; Berkman et al. 2008; Hokayem and BouJaoude 2008; Coalition of Scientific Societies 2008; The Gallup Poll 2008, 2009; Berkman and Plutzer 2011; Paz-y-Miño-C and Espinosa 2009a, b, 2011a), but the patterns of acceptance of evolution at the college level and its diverse subpopulations of students and faculty remain only partly known (but see Paz-y-Miño-C and Espinosa 2009a, b, 2011a). The latter applies particularly to the educators of future educators, that is college and university faculty specialized in training prospective teachers.

We considered it important to explore attitudes toward evolution among those acting as educators of prospective teachers for the following reasons: (1) Acceptance of evolution among school teachers, the "academic progeny" of the educators of prospective teachers, has been documented to be low (e.g., $14-69 \%$ of school teachers question or reject evolution; $40 \%$ do not accept human evolution; $43 \%$ are willing to dedicate "equal time" to science and ID; $13 \%$ explicitly advocate creationism and ID; and 20\% would agree to de-emphasize or omit evolution from their lessons if pressured by students or parents; statistical details in 
Moore 2002; National Science Teachers Association 2005; National Science Foundation 2006; Berkman and Plutzer 2010, 2011). And acceptance is sometimes even lower than among the general public (e.g., 30\% general public versus $47 \%$ high school biology teachers think that God guided human evolution; Berkman et al. 2008). Still, no connection has been proposed nor investigated between the views of these teachers about evolution and those of the scholars who trained them (i.e., educators of future educators). (2) Although attitudes toward evolution correlate positively with understanding of science/evolution and negatively with religiosity (Bishop and Anderson 1990; Downie and Barron 2000; Trani 2004; Paz-y-Miño-C and Espinosa 2011a), these parameters have not been quantified in subpopulations of educators of prospective teachers (Paz-y-Miño-C and Espinosa 2011a). Note that a cultural assumption has been that highly educated faculty are consistently supportive of science and remain distant from belief-based perspectives about the natural world (but see Ecklund and Scheitle 2007; Gross and Simmons 2009). (3) Because in a recent study we reported surprisingly high (30\%) religiosity among New England professors (Paz-y-Miño-C and Espinosa 2011a), we suspected differential religiosity between the educators of prospective teachers versus the general faculty and, therefore, lower levels of acceptance of evolution by the educators in respect to the rest of the professors. This suspicion was also based on the predominantly theistic (i.e., God-guided) views about evolution held by current schoolteachers nationwide (data above; Berkman and Plutzer 2010, 2011); and (4) because acceptance of evolution increases with level of education, from high school graduates (20\%; Brumfiel 2005; The Gallup Poll 2009) to university professors (94\%; Paz-y-Miño-C and Espinosa 2011a, this study), we considered it relevant to quantify support to evolution by the Ph.D.and doctorate-holder educators of prospective teachers in respect to the other populations (i.e., college students and professors outside the field of education).

Here we compare and contrast the views of a representative sample of New England educators of prospective teachers $(n=62)$ with those of the general faculty $(n=244)$ and college students $(n=827)$ who were polled in three areas (similar to Paz-y-Miño-C and Espinosa 2011a): (1) the controversy over evolution versus creationism versus ID, (2) their understanding of how science and the evolutionary process work, and (3) their religiosity. The samples of both educators of prospective teachers and the general faculty came from 35 colleges and universities; the students' data came from four representative New England institutions: public secular $(n=161)$, private secular $(n=298)$, religious I $(n=185)$, and religious II $(n=183)$. Assessing the perception of evolution by educators of prospective teachers versus the general faculty and the students in one of the historically most progressive regions of the U.S. is crucial for determining the magnitude of the impact of creationism and ID on attitudes toward science, reason, and education in science (Paz-yMiño-C and Espinosa 2011a). The New England states have among the highest evolution education standards in the U.S. (letter grade for coverage of evolution in state science standards: Connecticut $D$, Maine $C$, Massachusetts $B$, New Hampshire $A$, Rhode Island $B$, Vermont $B$; Mead and Mates 2009), however only two out of three New Englanders accept evolution (above). By understanding opinions about evolution among subpopulations of higher education audiences, whose impact in the educational system and society is direct and/ or imminent (e.g., "highly trained" educators of prospective teachers and general faculty, and "in-the-process-of-acquiringeducation" students/future graduates), we aim at improving the approach by which evolution and science are communicated to the public at large, thus contributing to curricular/pedagogical reform for their effective teaching in college and minimizing the negative effects of creationism and ID on the U.S. educational system (Paz-y-Miño-C and Espinosa 2009a, b, 2011a, b).

\section{Methods}

Because the statistical patterns of acceptance of evolution by educators of prospective teachers (the focus audience of this study) resulted in an intermediate position between the general faculty (highest scores) and the students (lowest scores), we describe and refer to these three subpopulations in the following order: first, the general faculty (Gen Fac); second, the educators of prospective teachers (Edu); and third, the students (Stu). We keep this approach in tables and figures to facilitate the presentation of the data, analysis, and discussion.

We sampled general faculty and educators of prospective teachers affiliated with 35 academic institutions (17 colleges, 18 universities) that were widely distributed geographically in all New England states (Connecticut, Maine, Massachusetts, New Hampshire, Rhode Island and Vermont; Tables 1 and 2, for institutional details see Table S1). In each state, we selected two public secular, two private secular and two religious colleges and/or universities, except for Maine where only one religious institution was identified (Table S1). We contacted via email (addresses obtained from institutional websites) 992 general faculty according to two criteria (Paz-y-Miño-C and Espinosa 2011a): first, members of the biology departments, or close equivalents (e.g., ecology and evolutionary biology, molecular and cell biology, natural sciences), of each institution (regardless of sex), who are usually highly educated in evolution; and second, a similar number of nonbiology faculty, across 40 different disciplines, who were selected randomly (sex ratio 1:1; Table $\mathrm{S} 1$ ). We also contacted via email (same as above) 506 educators of prospective teachers according to 


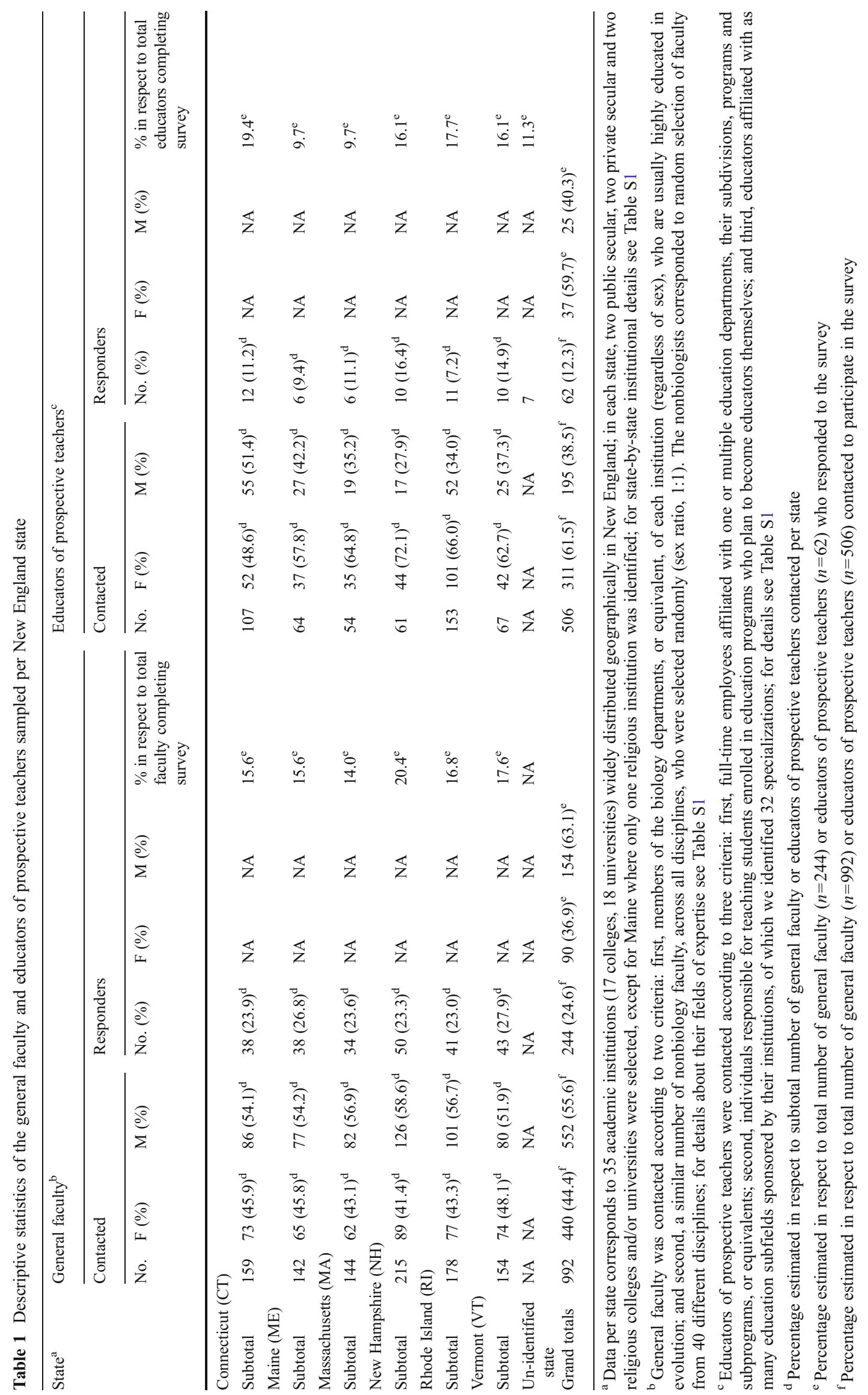


Table 2 Profile of the general faculty, educators of prospective teachers, and college students who participated in the study

\begin{tabular}{|c|c|c|c|c|}
\hline & $\begin{array}{l}\text { General faculty } \\
\text { No. }(\%)\end{array}$ & $\begin{array}{l}\text { Educators } \\
\text { No. }(\%)\end{array}$ & $\begin{array}{l}\text { Students } \\
\text { No. }(\%)\end{array}$ & $\begin{array}{l}\text { Grand Totals } \\
\text { No. }(\%)\end{array}$ \\
\hline Total & $244(21.5)^{\mathrm{a}}$ & $62(5.5)^{\mathrm{a}}$ & $827(73.0)^{\mathrm{a}}$ & $1,133(100)^{\mathrm{a}}$ \\
\hline Females & $90(36.9)^{\mathrm{b}}$ & $37(59.7)^{\mathrm{b}}$ & $509(61.5)^{\mathrm{b}}$ & $636(56.1)^{\mathrm{a}}$ \\
\hline Males & $154(63.1)^{\mathrm{b}}$ & $25(40.3)^{\mathrm{b}}$ & $318(38.5)^{\mathrm{b}}$ & $497(43.9)^{\mathrm{a}}$ \\
\hline $\mathrm{PhD}$ degree & $220(90.2)^{b}$ & $49(79.0)^{\mathrm{b}}$ & NA & $269(23.7)^{\mathrm{a}}$ \\
\hline Doctorate degree & $7(2.9)^{\mathrm{b}}$ & $5(8.1)^{\mathrm{b}}$ & NA & $12(1.1)^{\mathrm{a}}$ \\
\hline Masters degree & $17(6.9)^{\mathrm{b}}$ & $6(9.7)^{b}$ & NA & $23(2.0)^{\mathrm{a}}$ \\
\hline Bachelors degree & NA & $2(3.2)^{b}$ & NA & $2(0.2)^{\mathrm{a}}$ \\
\hline Freshman & NA & NA & $213(25.8)^{\mathrm{b}}$ & $213(18.8)^{\mathrm{a}}$ \\
\hline Sophomore & NA & NA & $192(23.2)^{\mathrm{b}}$ & $192(16.9)^{\mathrm{a}}$ \\
\hline Junior & NA & NA & $182(22.0)^{\mathrm{b}}$ & $182(16.1)^{\mathrm{a}}$ \\
\hline Senior & NA & NA & $240(29.0)^{\mathrm{b}}$ & $240(21.2)^{\mathrm{a}}$ \\
\hline New England & $104(42.6)^{\mathrm{bc}}$ & $25(40.3)^{\mathrm{bc}}$ & $630(76.2)^{\mathrm{bc}}$ & $759(67.0)^{\mathrm{a}}$ \\
\hline East Coast & $43(17.6)^{\mathrm{bd}}$ & $15(24.2)^{\mathrm{bd}}$ & $124(15.0)^{\mathrm{bd}}$ & $182(16.1)^{\mathrm{a}}$ \\
\hline Other states & $67(27.5)^{\text {be }}$ & $21(33.9)^{\mathrm{be}}$ & $50(6.0)^{\mathrm{be}}$ & $138(12.2)^{\mathrm{a}}$ \\
\hline Foreign countries & $30(12.3)^{\mathrm{bf}}$ & $1(1.6)^{\mathrm{bf}}$ & $23(2.8)^{\mathrm{bf}}$ & $54(4.7)^{\mathrm{a}}$ \\
\hline
\end{tabular}

${ }^{\text {a }}$ Percentages in respect to grand total number of participants or "responders" to the survey $(n=1,133)$, which is a fraction of the number of general faculty $(n=992)$ plus educators of prospective teachers $(n=506)$ and students $(n=17,621$; institutions: public $=7,982$, private $=3,806$, religious $\mathrm{I}=$ $3,910$, religious $I I=1,923)$ contacted via email and asked to take part in the study. For statistical details concerning profiles of those contacted, all responders, and their institutional affiliations and profiles see Tables S1 and S2

${ }^{\mathrm{b}}$ Percentages in respect to total number of participants per group of general faculty $(n=244)$, educators of prospective teachers $(n=62)$, and college students $(n=827$; institutions: public $=161$, private $=298$, religious $\mathrm{I}=185$, religious $\mathrm{II}=183$; see Table $\mathrm{S} 2$ for statistical details concerning students and their institutions)

${ }^{\mathrm{c}}$ New England: general faculty natives corresponded to MA, $13.7 \%$; CT, $6.8 \%$; VT, $6.8 \%$; ME, $5.9 \%$; NH, $4.9 \%$; and RI, $4.5 \%$; educators of prospective teachers natives corresponded to MA, $16.2 \%$; RI, 9.7\%; NH, 4.8\%; VT, 4.8\%; CT, 3.2\%; and ME, $1.6 \%$; and student natives corresponded to MA, 43.6\%; RI, $13.7 \%$; CT, $12.3 \%$; NH, 3.5\%; VT, 1.6 ; and ME, $1.5 \%$

${ }^{\mathrm{d}}$ East Coast: general faculty natives corresponded to NY, 9.6\%; PA, 4.4\%; NJ, 2.4\%; MD and VA, 1.2\%; educators of prospective teachers natives corresponded to NY, $12.9 \%$; PA, 4.8\%; MD, 3.3\%; NJ, 1.6\%; and VA, 1.6\%; and students natives corresponded to NY, 7.3\%; NJ, 3.8\%; PA, 1.7\%; $\mathrm{MD}, 1.2 \%$; DE and VA, $1.0 \%$

${ }^{\mathrm{e}}$ Other states: general faculty natives corresponded to CA, 7.3\%; MI, 3.6\%; CO and TX 2.5\%; IL, 2.0\%; OH, $1.6 \%$; and 17 other states plus Puerto Rico, 10.5\%; nativity of educators of prospective teachers corresponded to CA, 8.1\%; FL, 3.2\%; IL, 3.2\%; WI, 3.2\%; TX, 3.2\%; MO, OK, OR plus Puerto Rico, 6.6\%; and four unidentified states, $6.4 \%$; and nativity of students corresponded to AZ, CA, CO, FL, GA, HI, IL, IN, KT, MI, MN, MO, NM, OH, OR, SC, TN, TX, WA, WI, plus Puerto Rico and four unidentified states, $6.0 \%$

${ }^{\mathrm{f}}$ Foreign countries: general faculty corresponded to fifteen nationalities, including Europe and UK, 7.6\%; Canada, 2.4\%; and Australia, China, Libya, and Brazil, 2.3\%; educators of prospective teachers corresponded to one UK nationality, 1.6\%; and students corresponded to twenty nationalities, including Bosnia, Brazil, Canada, Cameroon, Cape Verde, Ecuador, France, Ghana, India, Japan, Korea, Latvia, Lebanon, Peru, Portugal, Philippines, Romania, Rwanda, UK, and Zimbabwe, 2.8\%

three criteria: first, full-time employees affiliated with one or multiple education departments, their subdivisions, programs and subprograms, or equivalents; second, individuals responsible for teaching students enrolled in education programs who, themselves, plan to become educators; and third, educators affiliated with as many education subfields sponsored by their institutions, of which we identified 32 specializations (Tables 1 and 2; for statistical details see Table S1). To compare the views of both the New England general faculty and the educators of prospective teachers with those of college students, we surveyed students from four representative New England institutions (email requests to all enrolled students; $n=17,621)$ : public secular University of Massachusetts Dartmouth (UMassD Pub: 7,982 students contacted), private secular Roger Williams University (RWU Priv: 3,806), religious I Providence College (PC Rel I: 3,910), and religious II Salve Regina University (SRU Rel II: 1,923) (Table 2; for detailed profiles of students and their institutions, see Table S2). Because the student population from the public secular institution was particularly large $(45.3 \%$ of all students), we included one private (Priv) and two religious institutions (Rel I and II) to improve the representation of both public versus private and secular versus religious student profiles in respect to the profiles of the Gen Fac and Edu, as follows: (1) Gen Fac and Edu contacted: 33.3\% public versus $66.7 \%$ private; Stu contacted: $45.3 \%$ public versus $54.7 \%$ private; and (2) Gen Fac and Edu contacted: $66.7 \%$ secular versus $33.3 \%$ religious; Stu contacted: 
$66.9 \%$ secular versus $33.1 \%$ religious (percentages generated from Tables S1 and S2).

General faculty, educators of prospective teachers, and student profiles of those who responded to the survey were comparable in respect to residency and workplace location (New England states) but differed, as we expected, in respect to place of birth (general faculty usually belong to diverse cultural backgrounds: New England 42.6\%, East Coast $17.6 \%$, other states $27.5 \%$, foreign countries $12.3 \%$; educators of prospective teachers, as faculty themselves, also belonged to diverse cultural backgrounds: New England 40.3\%, East Coast 24.2\%, other states 33.9\%, foreign countries 1.6\%; and students mean Pub+Priv+Rel I+Rel II: New England 76.2\%, East Coast $15.0 \%$, other states $6.0 \%$, foreign countries $2.8 \%$; Table 2). They also differed in respect to level of education (general faculty: Ph.D. holders, 90.2\%; doctoral degree or equivalent, 2.9\%; and masters degree, $6.9 \%$; educators of prospective teachers: Ph.D. holders, $79.0 \%$; doctoral degree or equivalent, $8.1 \%$; masters degree, 9.7\%; and bachelors degree, 3.2\%; and students mean Pub+ Priv +Rel I+Rel II: freshman, $25.8 \%$; sophomore, $23.2 \%$; junior, 22.0\%; and senior, 29.0\%; Table 2).

One thousand one hundred and thirty three general faculty $(n=244,21.5 \%)$, educators of prospective teachers $(n=62,5.5 \%)$, and students $(n=827,73.0 \%)$ responded to a ten-question anonymous and voluntary online survey (procedures similar to Paz-y-Miño-C and Espinosa 2009a, b, 2011a) to assess their views about evolution, creationism, and intelligent design (questions 1-7, below), as well as about their understanding of how the evolutionary process works (questions 8-9, below), and their religiosity (question 10, below). The level of understanding of science was assessed by asking three subquestions within the general online survey (as in Paz-y-Miño-C and Espinosa 2011a; for specifics see Indexes below). All participants were free to withdraw from the survey at any time; no risks or discomfort were involved in the study. The Institutional Review Board of UMassD approved the general faculty (surveyed during the first week of April and third week of May 2010), the educators of prospective teachers (fourth week of March and first week of April 2011), the UMassD students' study (second week of September 2009), the Human Subjects/Institutional Review Boards of RWU (third week of October 2009), PC (third week of April 2009), and SRU (fourth week of April 2011) approved the surveying of their own students. All participants answered questions 1-10 (but see exception in question 9, below) in order and were instructed to not skip or go back to previous questions to fix and/or compare answers. Questions 1-7 had five (a-e) choices per question; questions 8-9 and 10 were true/false and had five $(\mathrm{a}-\mathrm{e})$ or three $(\mathrm{a}-\mathrm{c})$ subcomponents (=each true/false), respectively. All choices per question, including the true/false options, were presented randomly, and only one choice was possible per question-except for questions 8-10 that allowed responders to select true or false in each of the subcomponents (i.e., questions 8-9: true/false for a or $\mathrm{b}$ or $\mathrm{c}$ or $\mathrm{d}$ or e; question 10: true/false for $\mathrm{a}$ or $\mathrm{b}$ or $\mathrm{c}$ ). For the purpose of reporting the data in this article and matching the description of each question with the figure legends (results, below), here we state the questions as follows (similar to Paz-y-Miño-C and Espinosa 2009a, b, 2011a):

Questions Addressing Views about Evolution, Creationism, and ID

Question 1: Evolution, creationism, and intelligent design in the science class. Which of the following explanations about the origin and development of life on Earth should be taught in science classes? $\mathrm{a}=$ evolution, $\mathrm{b}=$ equal time to evolution, creationism, intelligent design, $\mathrm{c}=$ creationism, $\mathrm{d}=$ intelligent design, $\mathrm{e}=$ do not know enough to say.

Question 2: Intelligent design (ID). Which of the following statements is consistent with ID? $a=$ ID is not scientific but has been proposed to counter evolution based on false claims, $b=$ ID is religious doctrine consistent with creationism, $c=$ no opinion, $d=I D$ is a scientific alternative to evolution and of equal scientific validity among scientists, $\mathrm{e}=$ ID is a scientific theory about the origin and evolution of life on Earth.

Question 3: Evolution and your reaction to it. Which of the following statements fits best your position concerning evolution? a=hearing about evolution makes me appreciate the factual explanation about the origin of life on Earth and its place in the universe, $b=$ hearing about evolution makes no difference to me because evolution and creationism are in harmony, $\mathrm{c}=$ hearing about evolution makes me uncomfortable because it is in conflict with my faith, $\mathrm{d}=$ hearing about evolution makes me realize how wrong scientists are concerning explanations about the origin of life on Earth and the universe, $\mathrm{e}=$ do not know enough to say.

Question 4: Your position about the teaching of human evolution. With which of the following statements do you agree? $\mathrm{a}=\mathrm{I}$ prefer science courses where evolution is discussed comprehensively and humans are part of it, $b=\mathrm{I}$ prefer science courses where plant and animal evolution is discussed but not human evolution, $\mathrm{c}=\mathrm{I}$ prefer science courses where the topic evolution is never addressed, $\mathrm{d}=\mathrm{I}$ avoid science courses with evolutionary content, $\mathrm{e}=\mathrm{do}$ not know enough to say.

Question 5: Evolution in science exams. Which of the following statements fits best your position concerning science exams? a=general faculty and educators of prospective teachers: instructors should have no problem giving exams with questions concerning evolution, or students: I have no problem answering questions concerning evolution, $\mathrm{b}=$ science exams should always include some questions 
concerning evolution, $\mathrm{c}=$ general faculty and educators of prospective teachers: students should prefer to not answer questions concerning evolution, or students: I prefer to not answer questions concerning evolution, $\mathrm{d}=$ general faculty and educators of prospective teachers: students should never answer questions concerning evolution, or students: I never answer questions concerning evolution, $\mathrm{e}=\mathrm{do}$ not know enough to say.

Question 6: Your willingness to discuss evolution. Select the statement that describes you best: $\mathrm{a}=\mathrm{I}$ accept evolution and express it openly regardless of other's opinions, $b=$ no opinion, $\mathrm{c}=\mathrm{I}$ accept evolution but do not discuss it openly to avoid conflicts with friends and family, $\mathrm{d}=\mathrm{I}$ believe in creationism and express it openly regardless of others' opinions, $\mathrm{e}=\mathrm{I}$ believe in creationism but do not discuss it openly to avoid conflicts with friends and family.

Question 7: Your overall opinion about evolution (question adapted from Miller et al. 2006). Select the statement with which you agree most about "evolution is": a=definitely true, $\mathrm{b}=$ probably true, $\mathrm{c}=$ definitely false, $\mathrm{d}=$ probably false, $\mathrm{e}=\mathrm{do}$ not know enough to say.

\section{Questions Addressing Views about the Evolutionary} Process

Question 8: An acceptable definition of evolution. Indicate if each of the following definitions of evolution is either true or false: $\mathrm{a}=$ gradual process by which the universe changes, it includes the origin of life, its diversification and the synergistic phenomena resulting from the interaction between life and the environment; $b=$ directional process by which unicellular organisms, like bacteria, turn into multicellular organisms, like sponges, which later turn into fish, amphibians, reptiles, birds, mammals and ultimately humans, the pinnacle of evolution; $\mathrm{c}=$ gradual process by which monkeys, such as chimpanzees, turn into humans; $\mathrm{d}=$ random process by which life originates, changes, and ends accidentally in complex organisms such as humans; $\mathrm{e}=$ gradual process by which organisms acquire traits during their lifetimes, such as longer necks, larger brains, resistance to parasites, and then pass on these traits to their descendants.

Question 9: Evidence about the evolutionary process. Indicate if each of the following statements about evolution is either true or false: a=all current living organisms are descendants of common ancestors, which have evolved for thousands, millions or billions of years; $b=$ humans are apes, relatives of chimpanzees, bonobos, gorillas, and orangutans; $\mathrm{c}=$ the hominid (human lineage) fossil record is so poor that scientists cannot tell with confidence that modern humans evolved from ancestral forms; $d=$ the origin of the human mind and consciousness cannot be explained by evolution, $\mathrm{e}=$ the universe, our solar system, and planet Earth are finely tuned to embrace human life.
Question Addressing Responders’ Religiosity

Question 10: Your religiosity. Indicate if each of the following statements about religiosity is either true or false, select all that apply (question adapted from Pew Global Attitudes Project 2007): $a=$ faith in God is necessary for morality, $b=$ religion is very important in my life, $\mathrm{c}=\mathrm{I}$ pray at least once a day.

Understanding of Science, Evolution, and Religiosity Indexes

The Pew Global Attitudes Project (2007) has used the three choices of Question 10 (above) to generate a religiosity index (RI), a powerful predictor of religious views worldwide (47 countries), which we applied to our New England general faculty, educators of prospective teachers, and student samples. RI ranges from 0 to 3 (least to most religious): +1 if responders believe that faith in God is necessary for morality, +1 if religion is very important in their lives, and +1 if they pray daily.

To account for the levels of understanding of science and the evolutionary process, we generated two descriptive indexes (science index (SI), evolution index (EI); similar to Paz-y-Miño-C and Espinosa 2011a), analogous to RI (above). Thus, we could compare levels of understanding of science (SI) and evolution (EI) with level of religiosity (RI). Note that scholars in the field of attitudes toward evolution have postulated (Bishop and Anderson 1990; Downie and Barron 2000; Trani 2004; Paz-y-Miño-C and Espinosa 2009a, b) and quantified (Paz-y-Miño-C and Espinosa 2011a) that these three factors are associated with an individual's acceptance of evolution. Our SI and EI range from 0 to 3 (lower to higher levels of understanding of science and evolution) and rely on three questions each, which were selected from a pool of five questions about science and ten about evolution (all part of the entire online surveys); the suitable questions for each index showed variability between the responses by the general faculty, the educators of prospective teachers, and the students, and were, therefore, informative for discriminating among the three groups: $\mathrm{SI}+1$ if responders rejected the idea that scientific theories are based on opinions by scientists, +1 if they disagreed with the notion that scientific arguments are as valid and respectable as their non-scientific counterparts, and +1 if they rejected the statement that crime-scene and accident-scene investigators use a different type of scientific method to investigate a crime or an accident $; \mathrm{EI}+1$ if responders rejected the idea that organisms acquire beneficial traits during their lifetimes and then pass on these traits to their descendants, +1 if they disagreed with the notion that during evolution monkeys such as chimpanzees can turn into humans, and +1 if they rejected the statement that the origin of the human mind and consciousness cannot be explained by evolution. 


\section{Statistical Analyses}

For the five-choice questions (1-7), we compared the New England general faculty (Gen Fac) versus the educators of prospective teachers $(\mathrm{Edu})$ versus the college students from four types of academic institutions (Stu: Pub+Priv + Rel I+Rel II) and analyzed separately the data generated in each of the questions (i.e., questions 1, 2, 3, 4, 5, 6, or 7; choices a-e). Data from each question were organized in $3 \times 5$ contingency tables, for example, Gen Fac, Edu, Stu $\times$ a-e (Chisquare tests, null hypotheses rejected at $P \leq 0.05$ ). Because questions $1,3,4,5,6$, or 7 had none or very few responders $(<5 \%$; note that Chi-square analyses are inaccurate when over $20 \%$ of the expected values are less than 5; Siegel and Castellan 1988) in one, two, or three of the choices (e or de or cde), we eliminated such choices and created $3 \times 2,3 \times 2,3 \times 2,3 \times 2,3 \times 3$, and $3 \times 2$ contingency tables for the remaining groups in each question, respectively (Chisquare tests, null hypotheses rejected at $P \leq 0.05$ ). For the true/false questions $8-9$ and 10, we organized the data corresponding to each subcomponent of the question (questions 8-9: subcomponents a-e; question 10: subcomponents a-c) in separate $2 \times 3$ contingency tables per each of the five or three subcomponents per question, respectively. For example, questions $8-9$, subcomponents a or b or $\mathrm{c}$ or $\mathrm{d}$ or e (each separately): true, false $\times$ Gen Fac, Edu, Stu, and question 10, subcomponents a or b or c (each separately): true, false $\times$ Gen Fac, Edu, Stu (Chi-square tests, null hypotheses rejected at $P \leq 0.05$ ). Note that for question 9 , we could only sample students from the religious II institution (SRU Rel II), thus we compared general faculty versus educators of prospective teachers versus the compiled data of students from three institutions: Pub+Priv+Rel II. Pairwise comparisons between relevant groups in all questions were analyzed with sign test two-tail, null hypotheses rejected at $P \leq 0.05$. Although we instructed participants to not skip questions, they could do it freely (see Human Subjects/Institutional Review Boards' policies, above); therefore, the total number of general faculty, educators of prospective teachers, or student responders per question varied, as reported in the figure captions (below): Gen Fac mean $=230, r=216-244$; Edu mean $=55, r=48-62$; and Stu mean $=681, r=576-791$ (note that 827 students responded as a whole to the 10 questions in the survey, but a maximum of 791 students completed the question with the most responses, i.e., question 2; see caption in Fig. 2 below). The SI, EI, and RI indexes (above) did range from 0 to 3 each; we generated them for the general faculty, the educators of prospective teachers, and the students, and analyzed the raw data of each index separately as function of subpopulation (i.e., SI, Gen Fac versus Edu versus Stu; EI, Gen Fac versus Edu versus Stu; and RI, Gen Fac versus Edu versus Stu) with Kruskal-Wallis one-way analysis of variance
(ANOVA) on ranks (null hypotheses rejected at $P \leq 0.05$ ). Pair-wise comparisons between relevant groups in each index were analyzed with a two-tailed Dunn test (appropriate for unequal group size comparisons in rank-based ANOVA; Siegel and Castellan 1988), null hypotheses rejected at $P \leq 0.05$. Linear regression was used to analyze the association between the $0-3$ levels of: SI (dependent variable) versus RI (independent variable), or EI (dependent variable) versus RI (independent variable), or EI (dependent variable) versus SI (independent variable) within each of the subpopulations (i.e., Gen Fac: SI versus RI, EI versus RI, and EI versus SI; Edu: SI versus RI, EI versus RI, and EI versus SI; and Stu: SI versus RI, EI versus RI, and EI versus SI). Because we hypothesized directionality in the inverse association between level of understanding of science/evolution (dependent variables) and level of religiosity (independent variable), as well as a positive association between level of understanding of evolution (dependent variable) and level of understanding of science (independent variable), we used one-tail tests to reject null hypothesis at $P \leq 0.05$.

\section{Results}

Survey Response Rates and Representativeness of the Samples

General Faculty Two hundred and forty four (24.6\%) of the 992 general faculty contacted to participate in the study ( $\mathrm{F}=$ $44.4 \%, \mathrm{M}=55.6 \%$; 40 disciplines) completed the survey (Table 1; see details in Table S1), a response rate comparable to analogous email/online studies $(=24 \%$, The Pew Research Center for the People \& the Press 2009). The average number of general faculty contacted per state was $165(r=142-215)$ and the average percent of responders per state was $25(r=23.0-27.9$; Table 1). Of all responders $(n=244), 36.9 \%$ were females and $63.1 \%$ were males (Table 1).

Educators of Prospective Teachers Sixty-two (12.3\%) of the 506 educators of prospective teachers contacted to participate in the study ( $\mathrm{F}=61.5 \%, \mathrm{M}=38.5 \% ; 32$ specializations) completed the survey (Table 1; see details in Table S1), a lower response rate than the general faculty (above) but consistent with the parameters of sample representativeness and statistical confidence (see "Representativeness of the Samples and Statistical Confidence" below); note that scholars of survey methodology no longer attribute primary validity to response rates (Groves et al. 2009; Berkman and Plutzer 2011) but rather to demographic segmentation and low variance in responses (van Bennekom 2002), as in this study. The average number of educators of prospective teachers contacted per state was $84(r=54-153$; Table 1), and the average percent 
of responders per state was $12(r=7.2-16.4$; Table 1$)$. Of all responders $(n=62), 59.7 \%$ were females and $40.3 \%$ were males (Table 1).

Students Eight hundred and twenty-seven (4.7\%) of the 17,621 students contacted to participate in the study completed the survey (Table 2; see details in Table S2). Response rate by students varied among institutions: Pub 161 (2.0\% of 7,982 contacted), Priv 298 (7.8\% of 3,806 contacted), Rel I 185 (4.7\% of 3,910 contacted), and Rel II 183 (9.5\% of the 1,923 contacted; Tables 2 and S2); these values were consistent with previous online sampling of these institutions where the demographic profile of participants in the surveys resembled closely the institutional profiles (Paz-y-Miño-C and Espinosa 2009a, b, 2011b). Of all responders $(n=827), 61.5 \%$ were females and $38.5 \%$ were males (Tables 2 and S2).

Representativeness of the Samples and Statistical Confidence We consider our samples statistically representative of the New England general faculty, educators of prospective teachers, and students for the following reasons: (1) The demographic segmentation of responders (i.e., percent of responders per state and type of institution as function of the segmentation of those contacted) was in accordance with the demographics of the entire populations participating in the study (Tables 1, 2, S1 and S2). Note that the response rate per state as function of those completing the survey was statistically similar between Gen Fac and Edu (Chi-square $=2.150$, $d f=5, P=0.828$; data extracted from Table 1), as well as the Gen Fac and Edu demographic profiles for New England, East Coast, and other states in the U.S. (Chi-square $=1.116, d f=2$, $P=0.572$; data extracted from Table 2), but not when foreign countries were included in the comparison (Chi-square $=$ 8.648, $d f=3, P=0.034$; data extracted from Table 2). Due to the rareness of international faculty $(1.6 \%)$ among the educators of prospective teachers, the latter did not skew the pattern of responses. The students' demographic profiles closely matched those of the entire student populations at their institutions, as well as their New England (76.2\%) and East Coast (15\%) upbringing (Tables 2 and S2); their responses were, therefore, pooled in a single group of students (Table 2) to homogenize their public-, private- secular or religious backgrounds, thus matching the students' profiles with those of the general faculty and the educators (note that independent analysis of New England student views about evolution have been published; Paz-y-Miño-C and Espinosa 2009a, b, 2011a). (2) The responses were tightly clustered (low variance is associated with satisfactory accuracy; see van Bennekom 2002) in each sample of Gen Fac, Edu, and Stu that we used to generate the index SI (variance: Gen $\mathrm{Fac}=0.495$, $\mathrm{Edu}=1.036$, and $\mathrm{Stu}=0.910$ ), EI (variance: $\mathrm{Gen} \mathrm{Fac}=0.431, \mathrm{Edu}=0.729$, and $\mathrm{Stu}=0.682$ ), and religiosity index RI (variance: Gen $\mathrm{Fac}=$
0.703, $\mathrm{Edu}=1.028$, and $\mathrm{Stu}=1.190$ ), from which we drew broad conclusions about acceptance of evolution in the context of the responders' understanding of science/evolution and level of religiosity (see Figs. 11, 12, and Discussion). (3) The margin of error per sample at $95 \%$ certainty and $50 \%$ response distribution was consistent with conventional polling of public opinions of variable sizes (see van Bennekom 2002), as follows: Gen $\mathrm{Fac} \pm 5.5 \%, \mathrm{Edu} \pm 11.7 \%$, and $\mathrm{Stu} \pm 3.3 \%$ (sample size calculator Raosoft 2011); note that by mentally adding and/or subtracting the margin of error values to/from the percentile responses in each question (results Figs. 1, 2, 3, 4, $5,6,7,8,9$ and 10, below) the differential response pattern between Gen Fac, Edu, and Stu persists. (4) The Gen Fac, Edu, and Stu held consistently high, middle, and low percentile levels of agreement/disagreement, respectively in each of the ten survey questions (except for a nonstatistical difference in question 5; see Fig. 5); and (5) the response rates of the general faculty $(24.6 \%)$, educators of prospective teachers $(12.3 \%)$, and students $(4.7 \%)$, in respect to the total populations contacted, were analogous to comparable studies of public opinions in the U.S. (The Pew Research Center for the People \& the Press 2009) and consistent with our previous studies (Paz-y-Miño-C and Espinosa 2009a, b, 2011a); note observation about modern views on surveys validity based on response rates (above).

\section{Views about Evolution, Creationism, and ID}

Evolution, Creationism, and Intelligent Design in the Science Class The general faculty, educators of prospective teachers, and students differed in their views about the teaching of evolution (Fig. 1; Chi-square $=23.968, d f=2$, $P \leq 0.001$ ): $96.3 \%$ of the general faculty versus $86.2 \%$ of the educators of prospective teachers versus $70.7 \%$ of the students considered that evolution should be taught in science classes as an explanation about the origin and development of life on Earth; in contrast, 3.7\% of the general faculty versus $13.8 \%$ of the educators of prospective teachers versus $29.3 \%$ of the students favored equal time to evolution, creationism and intelligent design. Educators of prospective teachers had intermediate percentile levels of support for the exclusive teaching of evolution between the general faculty (high) and the students (low), but were statistically similar to both groups; only the general faculty differed statistically from the students (sign test two-tail pair-wise comparison $P \leq 0.05$; Fig. 1). Although the general faculty support for the "equal time" option was negligible $(3.7 \%)$, at least one in seven educators of prospective teachers $(13.8 \%)$ and one in three students $(29.3 \%)$ favored it (Fig. 1). Note that concerning the "equal time" option, the views of each group were statistically different (sign test two-tail pair-wise comparison $P \leq 0.05$; Fig. 1 ), and the educators of prospective teachers placed intermediate. 


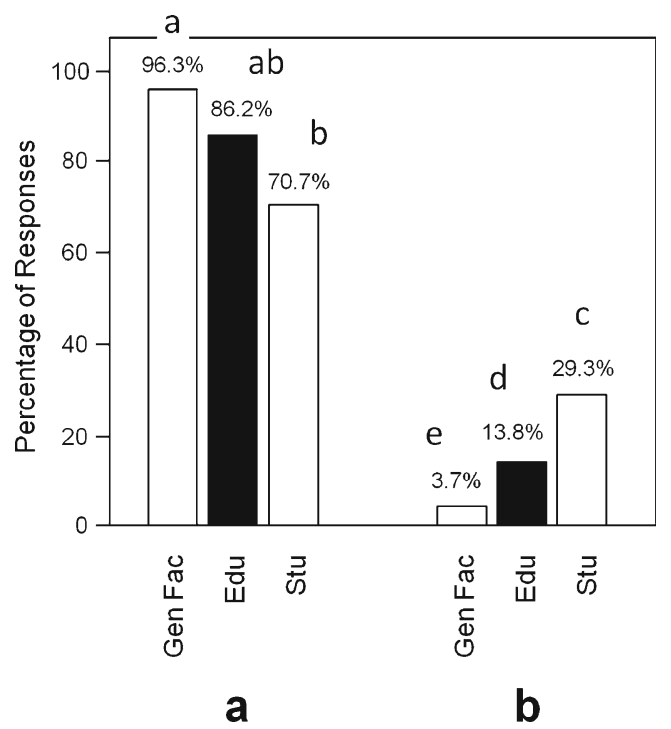

Fig. 1 Percentage of New England general faculty (Gen Fac, white bars left), educators of prospective teachers (Edu, black bars center), and college students (Stu, white bars right) who consider one of the following explanations about the origin and development of life on Earth should be taught in science classes: $a$ evolution and $b$ equal time to evolution, creationism, intelligent design. Comparisons among groups: Chi-square $=23.968, d f=2, P \leq 0.001$; lowercase letters indicate sign test two-tail pair-wise comparisons $P \leq 0.05$. Gen Fac, $n=241$; $E d u, n=58$; and Stu, $n=727$

Intelligent Design The general faculty and educators of prospective teachers had comparable opinions about ID, which differed from the students' variable perception of ID (Fig. 2; Chi-square $=50.836, d f=8, P \leq 0.001): 46.7 / 45.5 \%$ of the general faculty and $41.9 / 40.3 \%$ of the educators of prospective teachers versus $22.9 / 27.4 \%$ of the students perceived ID as

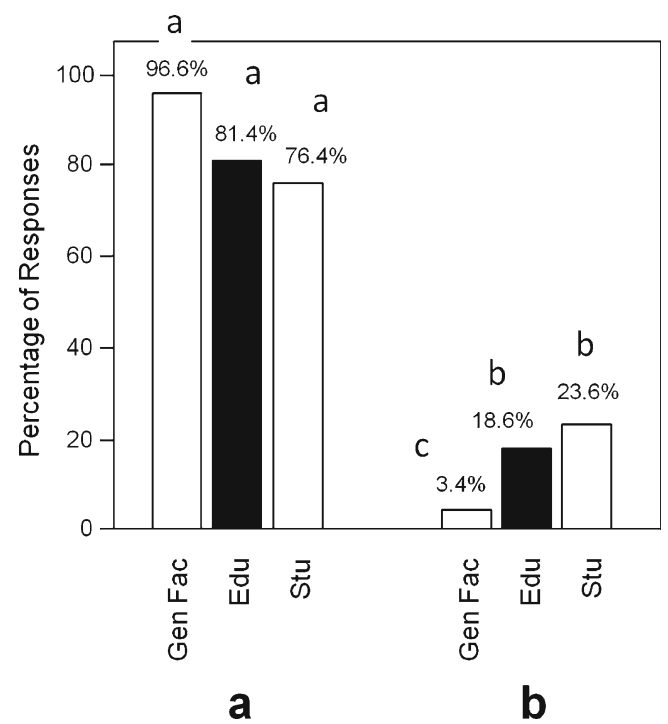

Fig. 3 Percentage of New England general faculty (Gen Fac, white bars left), educators of prospective teachers (Edu, black bars center), and college students (Stu, white bars right) who think one of the following statements fits best their position concerning evolution: $a$ hearing about evolution makes me appreciate the factual explanation about the origin of life on Earth and its place in the universe; and $b$ hearing about evolution makes no difference to me because evolution and creationism are in harmony. Comparisons among groups: Chisquare $=18.538, d f=2, P \leq 0.001$; lowercase letters indicate sign test two-tail pair-wise comparisons $P \leq 0.05$. Gen Fac, $n=236$; $E d u, n=59$; and $S t u, n=712$

either not scientific and proposed to counter evolution based on false claims or as religious doctrine consistent with creationism, respectively. A small percent of the general faculty and educators of prospective teachers in comparison to a higher

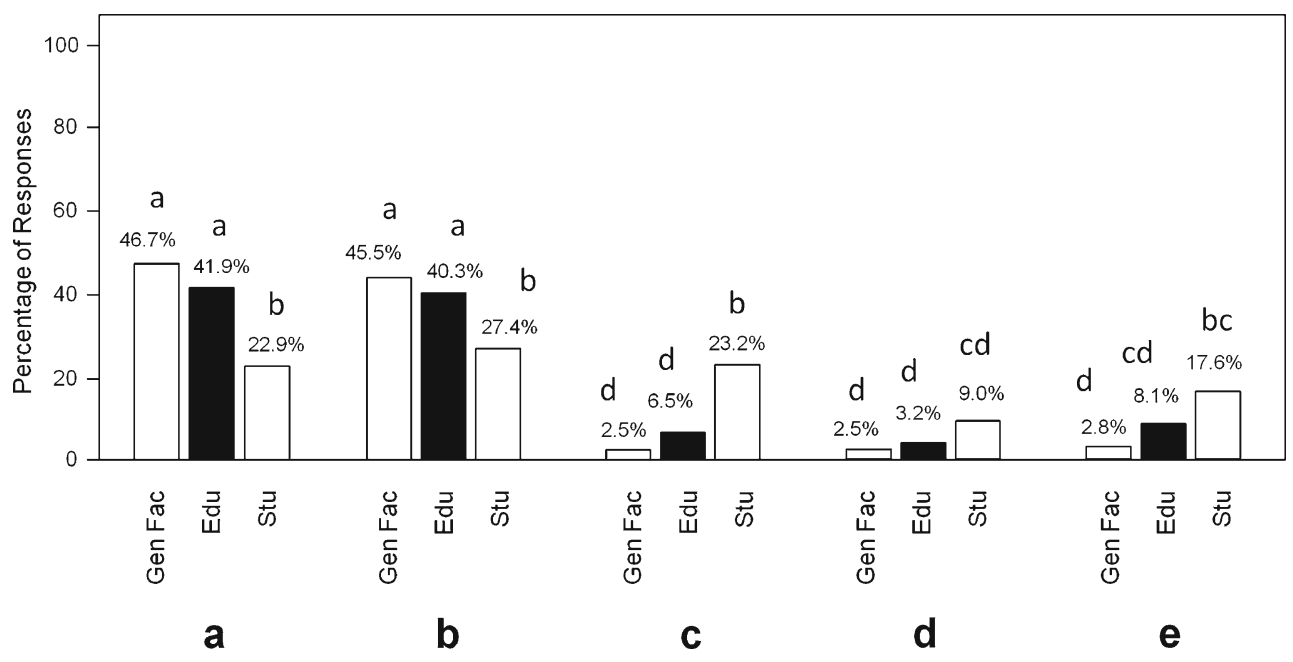

Fig. 2 Percentage of New England general faculty (Gen Fac, white bars left), educators of prospective teachers (Edu, black bars center) and college students (Stu, white bars right) who consider one of the following statements to be consistent with Intelligent Design (ID): $a$ ID is not scientific but has been proposed to counter evolution based on false claims; $b$ ID is religious doctrine consistent with creationism; $c$ no opinion; $d$ ID is a scientific alternative to evolution and of equal scientific validity among scientists; and $e$ ID is a scientific theory about the origin and evolution of life on Earth. Comparisons among groups: Chi-square $=50.836, d f=8, P \leq 0.001$; lowercase letters indicate sign test two-tail pair-wise comparisons $P \leq 0.05$. Gen Fac, $n=244$; Edu, $n=62$; and $S t u, n=791$ 


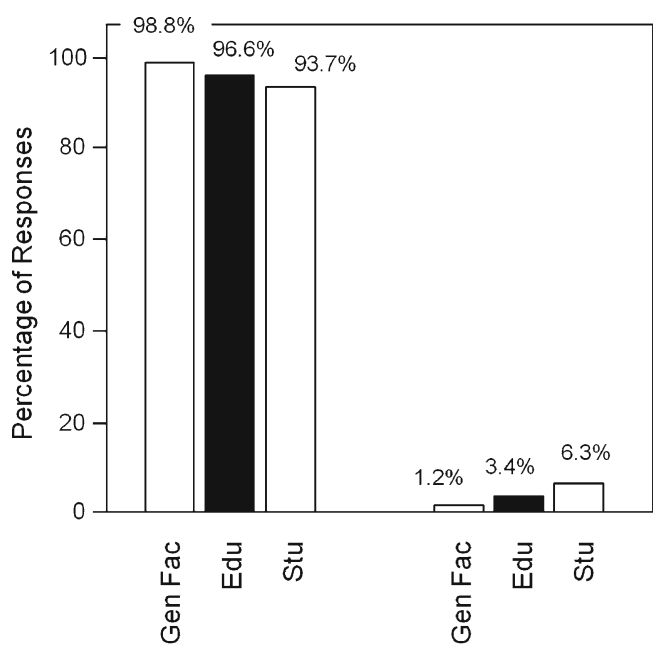

a

b

Fig. 4 Percentage of New England general faculty (Gen Fac, white bars left), educators of prospective teachers (Edu, black bars center), and college students (Stu, white bars right) who agree with one of the following statements concerning their own education: $a$ I prefer science courses where evolution is discussed comprehensively and humans are part of it; and $b$ I prefer science courses where plant and animal evolution is discussed but not human evolution. Comparisons among groups: Chi-square $=3.931, d f=2, P=0.14$. Gen Fac, $n=242$; $E d u, n=59$; and $S t u, n=702$

percent of students had either no opinion about ID $(2.5 \%$ general faculty, $6.5 \%$ educators of prospective teachers, $23.2 \%$ students), considered ID a scientific alternative to

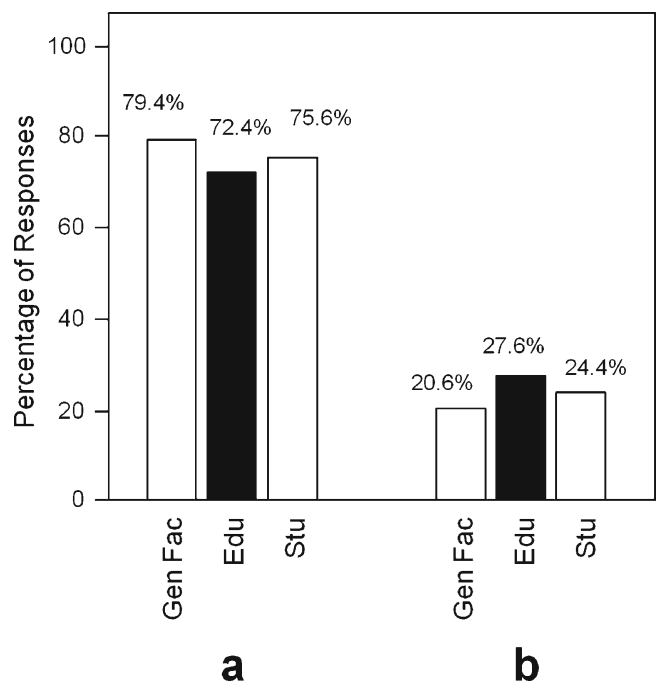

Fig. 5 Percentage of New England general faculty (Gen Fac, white bars left), educators of prospective teachers (Edu, black bars center), and college students (Stu, white bars right) who agree with one of the following statements concerning evolution in science exams: $a$ Gen Fac and Edu: instructors should have no problem giving exams with questions concerning evolution, or Stu: I have no problem answering questions concerning evolution; and $b$ science exams should always include some questions concerning evolution. Comparisons among groups: chi-square $=1.34, d f=2, P=0.512$. Gen Fac, $n=238 ; E d u, n=$ 58; and $S t u, n=711$

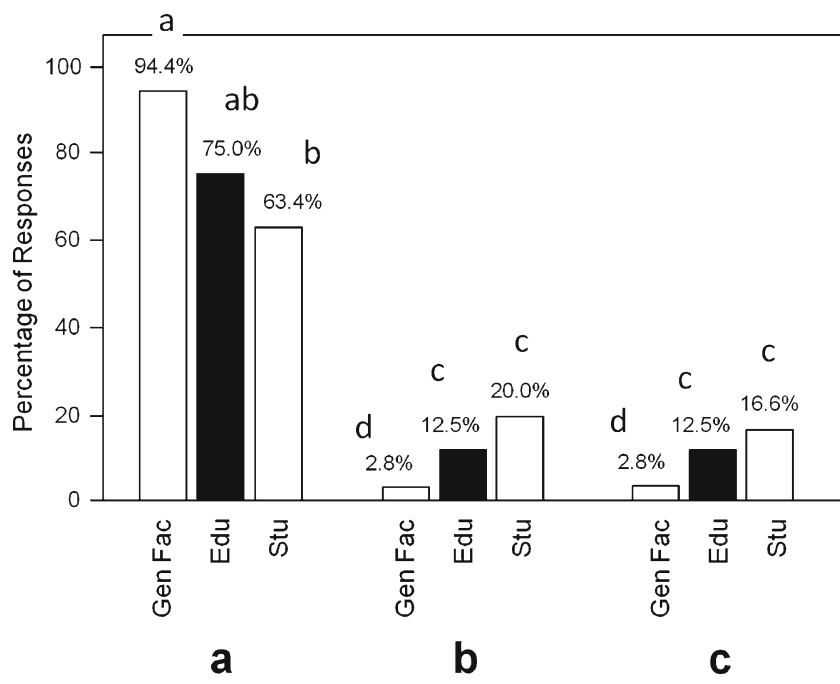

Fig. 6 Percentage of New England general faculty (Gen Fac, white bars left), educators of prospective teachers (Edu, black bars center), and college students (Stu, white bars right) who believe one of the following statements describes them best: $a$ I accept evolution and express it openly regardless of others' opinions; $b$ no opinion; and $c$ I accept evolution but do not discuss it openly to avoid conflicts with friends and family. Comparisons among groups: Chi-square $=28.022$, $d f=4, P \leq 0.001$; lowercase letters indicate sign test two-tail pair-wise comparisons $P \leq 0.05$. Gen Fac, $n=216 ; E d u, n=48$; and Stu, $n=695$

evolution and of equal scientific validity among scientists ( $2.5 \%$ general faculty, $3.2 \%$ educators of prospective teachers, $9.0 \%$ students), or thought of ID as a scientific theory about the origin of life on Earth $(2.8 \%$ general faculty, $8.1 \%$ educators of prospective teachers, $17.6 \%$ students; sign test two-tail pair-wise comparisons $P \leq 0.05$; Fig. 2).

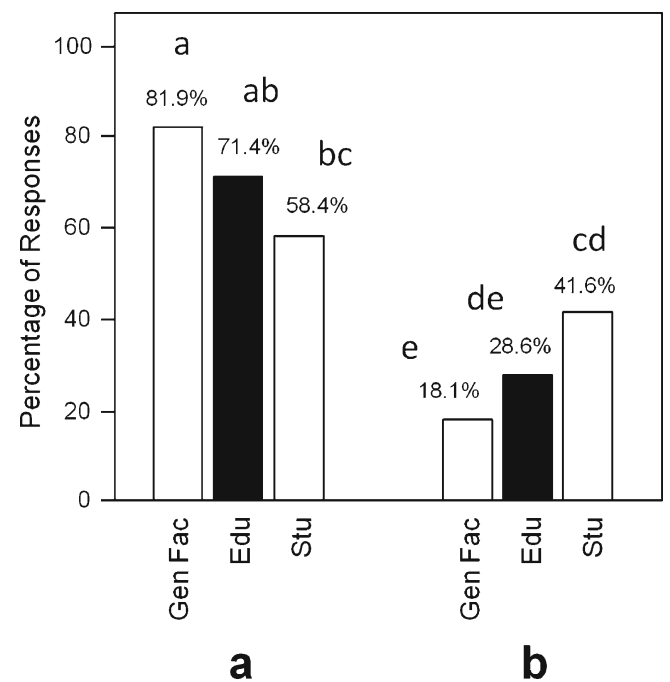

Fig. 7 Percentage of New England general faculty (Gen Fac, white bars left), educators of prospective teachers (Edu, black bars center), and college students (Stu, white bars right) who think evolution is: $a$ definitely true and $b$ probably true. Comparisons among groups: chisquare $=13.835, d f=2, P \leq 0.001 ;$ small case letters indicate sign test two-tail pair-wise comparisons $P \leq 0.05$. Gen Fac, $n=216$; $E d u, n=49$; and $S t u, n=677$ 


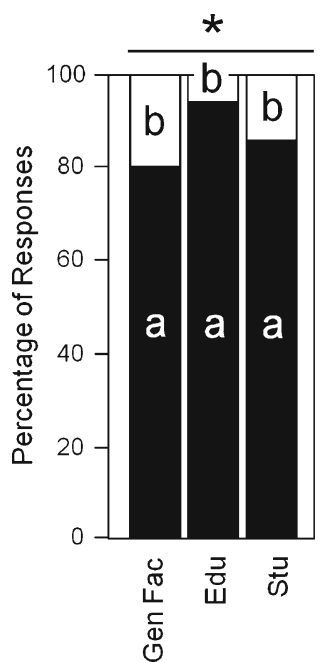

a

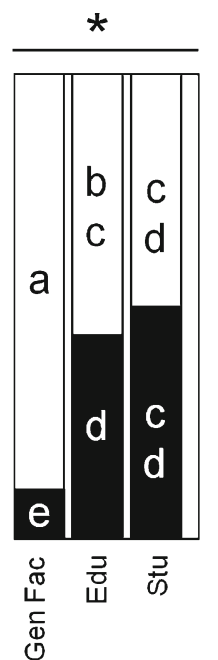

b

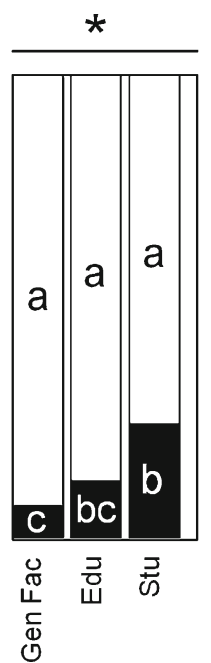

C

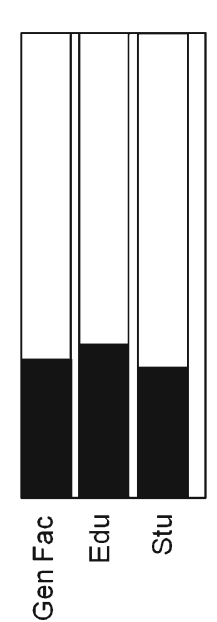

d

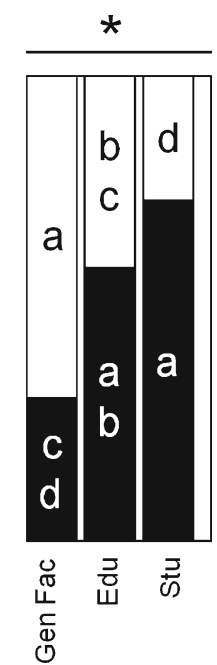

e

Fig. 8 Percentage of New England general faculty (Gen Fac), educators of prospective teachers $(E d u)$, and college students $(S t u)$ who consider the following definitions of evolution to be either true (black part of the bar) or false (white part of the bar): a gradual process by which the universe changes, it includes the origin of life, its diversification and the synergistic phenomena resulting from the interaction between life and the environment; $b$ directional process by which unicellular organisms, like bacteria, turn into multi cellular organisms, like sponges, which later turn into fish, amphibians, reptiles, birds, mammals and ultimately humans, the pinnacle of evolution; $c$ gradual process by which monkeys, such as chimpanzees, turn into humans; $d$ random process by which life originates,

changes, and ends accidentally in complex organisms such as humans; and $e$ gradual process by which organisms acquire traits during their lifetimes, such as longer necks, larger brains, resistance to parasites, and then pass on these traits to their descendants. Comparisons within groups (asterisks indicate significance): $a$ Chi-square $=8.532, d f=2, P=0.014$; $b$ Chi-square $=36.748, d f=2, P \leq 0.001 ; c$ Chi-square $=14.755, d f=2$, $P \leq 0.001 ; d$ Chi-square $=0.655, d f=2, P=0.721 ; e$ Chi-square $=40.081$, $d f=2, P \leq 0.001$. Lowercase letters indicate sign test two-tail pair-wise comparisons within groups $P \leq 0.05$. Gen Fac, $n=221 ; E d u, n=53$; and Stu, $n=733$

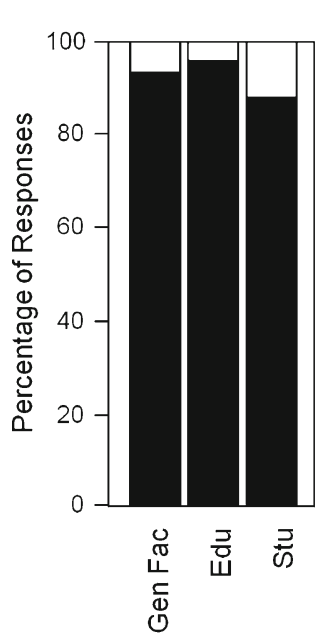

a

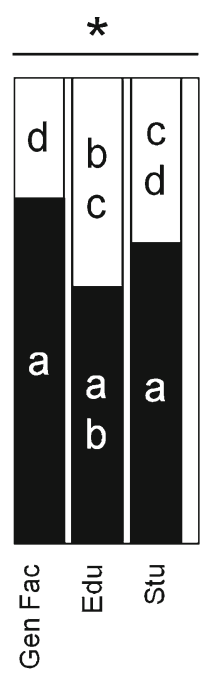

b

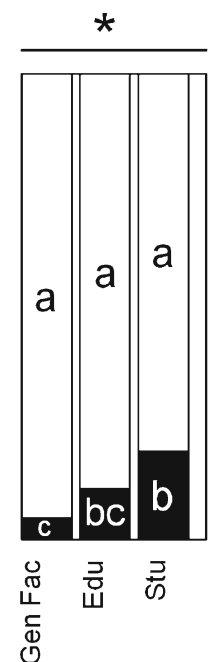

C

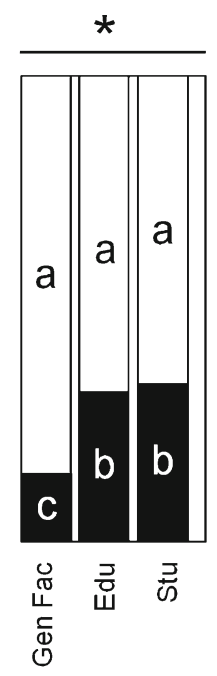

d

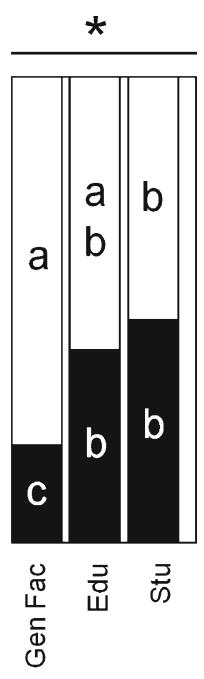

e

Fig. 9 Percentage of New England general faculty (Gen Fac), educators of prospective teachers $(E d u)$, and college students $(S t u)$ who consider the following statements about evolution to be either true (black part of the bar) or false (white part of the bar): a all current living organisms are descendants of common ancestors, which have evolved for thousands, millions, or billions of years; $b$ humans are apes, relatives of chimpanzees, bonobos, gorillas, and orangutans; $c$ the hominid (human lineage) fossil record is so poor that scientists cannot tell with confidence that modern humans evolved from ancestral forms;

$d$ the origin of the human mind and consciousness cannot be explained by evolution; and $e$ the universe, our solar system and planet Earth are finely tuned to embrace human life. Comparisons within groups (asterisks indicate significance): $a$ Chi-square $=5.101, d f=$ 2, $P=0.078 ; b$ Chi-square $=7.907, d f=2, P=0.019 ; c$ Chi-square $=$ 11.212, $d f=2, P=0.004 ; d$ Chi-square $=11.714, d f=2, P=0.003 ; e$ Chi-square $=16.392, d f=2, P \leq 0.001$. Lowercase letters indicate sign test two-tail pair-wise comparisons within groups $P \leq 0.05$. Gen Fac, $n=221 ; E d u, n=53$; and Stu, $n=583$ 


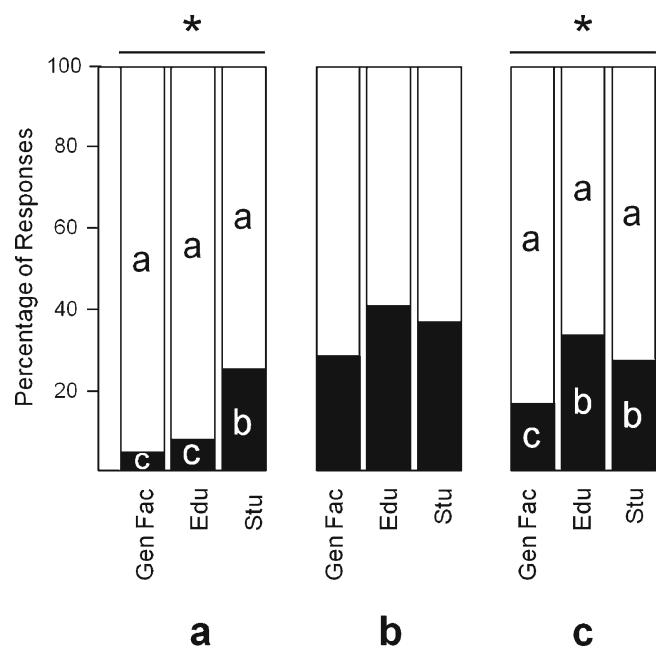

Fig. 10 Percentage of New England general faculty (Gen Fac), educators of prospective teachers $(E d u)$, and college students $(S t u)$ who consider the following statements about religiosity to be either true (black part of the bar) or false (white part of the bar): $a$ faith in God is necessary for morality; $b$ religion is very important in my life; and $c$ I pray at least once a day. Comparisons within groups (asterisks indicate significance): $a$ Chi-square $=21.033, d f=2, P \leq 0.001 ; b$ Chi-square $=$ 3.733, $d f=2, P=0.155 ; c$ Chi-square $=7.644, d f=2, P=0.022$. Lowercase letters indicate sign test two-tail pair-wise comparisons within groups $P \leq 0.05$. Gen Fac, $n=221 ; E d u, n=53$; and Stu, $n=587$

Evolution and Responders' Reaction to it The general faculty, educators of prospective teachers, and students had distinctive positions about evolution (Fig. 3; Chi-square= $18.538, d f=2, P \leq 0.001): 96.6 \%$ of the general faculty, $81.4 \%$ of the educators of prospective teachers and $76.4 \%$ of the students thought that hearing about evolution made them appreciate the factual explanation about the origin of life on Earth and its place in the universe; educators of prospective teachers had intermediate percentile level of agreement with this position between the general faculty (high) and the students (low), but the three groups were statistically similar (sign test two-tail pair-wise comparison $P \leq 0.05$; Fig. 3). Although only $3.4 \%$ of the general faculty considered that hearing about evolution makes no difference because evolution and creationism are in harmony, at least one in five educators of prospective teachers $(18.6 \%)$ and one in four students $(23.6 \%)$ hold this position (Fig. 3). Note that concerning the "harmony" option, the views of the educators of prospective teachers were statistically similar to the students' and these two groups differed from the general faculty (sign test two-tail pair-wise comparison $P \leq 0.05$; Fig. 3).

Position about the Teaching of Human Evolution The general faculty, educators of prospective teachers, and students agreed on their views about the teaching of human evolution (Fig. 4; Chi-square $=3.931, d f=2, P=0.14$ ): $98.8 \%$ of the general faculty, $96.6 \%$ of the educators of prospective teachers, and $93.7 \%$ of the students preferred science courses where evolution is discussed comprehensively and humans are part of it, and only $1.2 \%$ of the general faculty, $3.4 \%$ of the educators of prospective teachers, and $6.3 \%$ of the students preferred evolution discussions about plants and animals but not humans. In each case (i.e., science courses including or excluding human evolution) the general faculty, educators of prospective teachers and student responses were statistically similar (sign test two-tail pairwise comparisons $P \geq 0.05$; Fig 4 ).

Evolution in Science Exams The general faculty, educators of prospective teachers, and students shared opinions about the inclusion of evolution in science exams (Fig. 5; Chisquare $=1.34, d f=2, P=0.512): 79.4 \%$ of the general faculty, $72.4 \%$ of the educators of prospective teachers, and $75.6 \%$ of the students had no problem with either instructors including questions concerning evolution in exams or answering questions concerning evolution in exams, respectively, and $20.6 \%$ of the general faculty, $27.6 \%$ of the educators of prospective teachers, and $24.4 \%$ of the students considered that exams should always include some questions concerning evolution. In each case (i.e., optional or required inclusion of questions about evolution in exams) the general faculty, educators of prospective teachers and student responses were statistically similar (sign test two-tail pair-wise comparisons $P \geq 0.05$, Fig. 5).

Willingness to Discuss Evolution The general faculty, educators of prospective teachers, and students differed in their willingness to offer opinions about evolution (Fig. 6; Chisquare $=28.022, d f=4, P \leq 0.001): 94.4 \%$ of the general faculty versus $75.0 \%$ of the educators of prospective teachers versus $63.4 \%$ of the students indicated acceptance of evolution and of expressing it openly regardless of others' opinions, $2.8 \%$ of the general faculty versus $12.5 \%$ of the educators of prospective teachers versus $20.0 \%$ of the students preferred not to comment on this issue, and $2.8 \%$ of the general faculty versus $12.5 \%$ of the educators of prospective teachers versus $16.6 \%$ of the students admitted accepting evolution but not discussing it openly to avoid conflicts with friends and family. Educators of prospective teachers had intermediate percentile levels of support for each of these three positions between the general faculty and the students and were statistically similar to the students in each choice. Educators and general faculty were statistically similar in respect to the option "acceptance of evolution openly," but differed in respect to the "no opinion" and "acceptance of evolution privately" options; note that the general faculty differed statistically from the students in all cases (sign test two-tail pairwise comparison $P \leq 0.05$; Fig. 6).

Overall Opinion about Evolution The general faculty, educators of prospective teachers, and students differed in their 
overall opinion about evolution (Fig. 7; Chi-square $=13.835$, $d f=2, P \leq 0.001): 81.9 \%$ of the general faculty versus $71.4 \%$ of the educators of prospective teachers versus $58.4 \%$ of the students thought that evolution is definitely true, and $18.1 \%$ of the general faculty versus $28.6 \%$ of the educators of prospective teachers versus $41.6 \%$ of the students thought that evolution is probably true. Educators of prospective teachers had intermediate percentile level of support for each of these two positions between the general faculty and the students, but were statistically similar to both groups; only the general faculty differed statistically from the students (sign test two-tail pair-wise comparison $P \leq$ 0.05; Fig. 7).

\section{Views about the Evolutionary Process}

An Acceptable Definition of Evolution There was noticeable variation in the views of the general faculty versus the educators of prospective teachers versus the students about alternative definitions of evolution (Fig. 8): $80 \%$ of the general faculty, $94.3 \%$ of the educators of prospective teachers, and $85.1 \%$ of the students considered definition a of evolution as true: gradual process by which the universe changes, it includes the origin of life, its diversification and the synergistic phenomena resulting from the interaction between life and the environment; faculty and student responses were statistically similar (within group comparisons Chi-square $=8.532, d f=2$, $P=0.014$ ); note that definition a was the most comprehensive included in the survey. Eleven percent of the general faculty versus $39.6 \%$ of the educators of prospective teachers versus $50.3 \%$ of the students considered definition b of evolution as true: directional process by which unicellular organisms, like bacteria, turn into multicellular organisms, like sponges, which later turn into fish, amphibians, reptiles, birds, mammals and ultimately humans, the pinnacle of evolution (within group comparisons chi-square $=36.748, d f=2, P \leq 0.001$ ); the general faculty and the educators of prospective teachers correctly rejected this definition, but their responses were significantly different from each other $(89 \%$ of the general faculty versus $60.4 \%$ considered it false, sign test two-tail pair-wise comparison $P \leq 0.05$; Fig. 8 ); despite the $39.6 \%$ true versus $60.4 \%$ false responses by the educators of prospective teachers, their views did not differ statistically from the students', but the students true versus false responses were similar to chance (sign test two-tail pair-wise comparisons $P \geq 0.05$; Fig. 8); note that definition $b$ implies purpose in evolution and goal toward "humanity." Six percent of the general faculty versus $13.2 \%$ of the educators of prospective teachers versus $25.3 \%$ of the students considered definition c of evolution as true: gradual process by which monkeys, such as chimpanzees, turn into humans (within group comparisons chi-square= 14.755, $d f=2, P \leq 0.001$ ); the three groups correctly rejected this definition ( $94 \%$ of the general faculty, $86.8 \%$ of the educators of prospective teachers and $74 . \%$ of the students considered it false, sign test two-tail pair-wise comparison $P \leq 0.05$; Fig. 8); note that definition c asserts that chimpanzees are "monkeys" and that humans evolved from them. Thirty percent of the general faculty, $34.0 \%$ of the educators of prospective teachers and $28.5 \%$ of the students considered definition $\mathrm{d}$ of evolution as true: random process by which life originates, changes, and ends accidentally in complex organisms such as humans; the three groups correctly rejected this definition $(70 \%$ of the general faculty, $66 \%$ of the educators of prospective teachers, and $71.5 \%$ of the students considered it false) and their responses were statistically similar (within group comparisons Chi-square $=0.655, d f=2, P=0.721$ ); note that definition d implies that evolution is random and accidental. Thirty-one percent of the general faculty versus $58.5 \%$ of the educators of prospective teachers versus $74.8 \%$ of the students considered definition e of evolution as true: gradual process by which organisms acquire traits during their lifetimes, such as longer necks, larger brains, resistance to parasites, and then pass on these traits to their descendants (within group comparisons Chi-square $=40.081, d f=2, P \leq 0.001$ ); $69 \%$ of the general faculty versus $41.5 \%$ of the educators of prospective teachers versus $25.2 \%$ of the students correctly rejected this Lamarckian definition; note that the general faculty, educators of prospective teachers and students true/ false responses were distinctive (Gen Fac 31/69\% versus Edu $58.5 / 41.5 \%$ versus Stu 74.8/25.2\%), however, the views of the general faculty differed statistically from both the opinions of the educators of prospective teachers and the students,' the latter two groups were statistically similar (sign test two-tail pair-wise comparisons $P \leq 0.05$; Fig. 8).

Evidence about the Evolutionary Process The general faculty, educators of prospective teachers, and students varied in their understanding of how evolution works (Fig. 9): 94\% of the general faculty, $96.2 \%$ of the educators of prospective teachers, and $88.2 \%$ of the students correctly considered statement a as true: all current living organisms are descendants of common ancestors, which have evolved for thousands, millions or billions of years; responses by the three groups were statistically similar (within group comparisons Chi-square $=5.101, d f=2, P=0.078)$. Seventy-four percent of the general faculty versus $54.7 \%$ of the educators of prospective teachers versus $65.4 \%$ of the students correctly considered statement $\mathrm{b}$ as true: humans are apes, relatives of chimpanzees, bonobos, gorillas, and orangutans; true/false responses by the three groups differed distinctively (within group comparisons Chi-square $=7.907$, $d f=2, P=0.019)$ and although the general faculty and students true versus false responses were comparable to each other and both were different than chance (sign test two-tail pair-wise comparison $P \leq 0.05$; Fig. 9), the educators of prospective teachers true versus false responses were similar 
to chance (sign test two-tail pair-wise comparison $P \geq 0.05$; Fig. 9). Four percent of the general faculty versus $11.3 \%$ of the educators of prospective teachers versus $18.7 \%$ of the students considered statement $\mathrm{c}$ as true: the hominid (human lineage) fossil record is so poor that scientists cannot tell with confidence that modern humans evolved from ancestral forms (within group comparison Chi-square $=11.212, d f=2$, $P=0.004$ ); educators of prospective teachers' responses were statistically similar to both the general faculty and the students; however, significantly less general faculty than students thought that this statement was true (sign test twotail pair-wise comparisons $P \leq 0.05$; Fig. 9). Note that $96 \%$ of the general faculty, $88.7 \%$ of the educators of prospective teachers, and $81.3 \%$ of the students correctly rejected this statement and these responses were statistically similar (sign test two-tail pair-wise comparisons $P \geq 0.05$; Fig. 9). Fifteen percent of the general faculty versus $32.0 \%$ of the educators of prospective teachers versus $34.7 \%$ of the students considered statement $\mathrm{d}$ as true: the origin of the human mind and consciousness cannot be explained by evolution (within group comparison Chi-square $=11.714, d f=2, P=0.003$ ); the general faculty responses were statistically different from both the educators of prospective teachers and the students (sign test two-tail pair-wise comparisons $P \leq 0.05$; Fig. 9); note that $85 \%$ of the general faculty, $68 \%$ of the educators of prospective teachers, and $65.3 \%$ of the students correctly rejected this statement and their responses were statistically similar (sign test two-tail pair-wise comparisons $P \geq 0.05$; Fig. 9). Twenty-one percent of the general faculty versus $41.5 \%$ of the educators of prospective teachers versus $47.3 \%$ of the students considered statement e as true: the universe, our solar system and planet Earth are finely tuned to embrace human life (within group comparisons Chisquare $=16.392, d f=2, P \leq 0.001$ ); significantly less general faculty than both educators of prospective teachers and students thought that this statement was true (sign test two-tail pair-wise comparisons $P \leq 0.05$; Fig. 9). Although $79 \%$ of the general faculty and $58.5 \%$ of the educators of prospective teachers correctly rejected this statement, and their responses were comparable to each other but different than chance (sign test two-tail pair-wise comparison $P \leq$ 0.05 ; Fig. 9), the students' true versus false responses were similar to chance (sign test two-tail pair-wise comparison $P \geq 0.05$; Fig. 9).

\section{Responders' Religiosity}

Your Religiosity The general faculty, educators of prospective teachers, and students varied in their religiosity (Fig. 10): $5 \%$ of the general faculty, $7.5 \%$ of the educators of prospective teachers, and $25.1 \%$ of the students considered statement a as true: faith in God is necessary for morality (within group comparisons Chi-square $=21.033, d f=2, P \leq 0.001$ ); significantly less general faculty and educators of prospective teachers than students thought that this statement was true (sign test twotail pair-wise comparisons $P \leq 0.05$; Fig. 10). Note that $95 \%$ of the general faculty, $92.5 \%$ of the educators of prospective teachers, and $74.9 \%$ of the students considered this statement as false and their responses were statistically similar (sign test two-tail pair-wise comparisons $P \geq 0.05$; Fig. 10). Twenty-nine percent of the general faculty, $41.5 \%$ of the educators of prospective teachers, and $37.3 \%$ of the students considered statement $\mathrm{b}$ as true: religion is very important in my life (within group comparisons Chi-square $=3.733, d f=2, P=0.155$; Fig. 10). Note that $71 \%$ of the general faculty, $59.5 \%$ of the educators of prospective teachers, and $62.7 \%$ of the students thought that this statement was false; true/false responses by the three groups were statistically similar (sign test two-tail pair-wise comparisons $P \geq 0.05$; Fig. 10). Seventeen percent of the general faculty, $34.0 \%$ of the educators of prospective teachers, and $27.6 \%$ of the students considered statement $\mathrm{c}$ as true: I pray at least once a day (within group comparisons Chisquare $=7.644, d f=2, P=0.022$; Fig. 10). The general faculty responses were statistically different from both the educators of prospective teachers and the students (sign test two-tail pairwise comparisons $P \leq 0.05$; Fig. 10). Note that $83 \%$ of the general faculty, $66 \%$ of the educators of prospective teachers, and $72.4 \%$ of the students rejected this statement and these responses were statistically similar (sign test two-tail pair-wise comparisons $P \geq 0.05$; Fig. 10).

Understanding of Science, Evolution, and Religiosity Indexes

Understanding of Science Index The general faculty, educators of prospective teachers, and students differed in their levels of understanding science: the educators of prospective teachers had intermediate levels of understanding science (Edu SI=1.96), between the general faculty (Gen Fac SI= 2.49) and the students (Stu SI=1.80; Fig. 11; KruskalWallis one-way ANOVA on ranks, $\mathrm{H}=89.365, d f=2, P \leq$ $0.001)$. Note that the general faculty SI was statistically different from both the educators of prospective teachers SI and the students' SI (Dunn test, two-tail pair-wise comparisons $P \leq 0.05$; Fig. 11) and that the latter two groups were statistically similar. The three groups responded distinctively to each of the subcomponents of choice a, question 10 (above), as follows: first subcomponent (scientific theories are based on opinions by scientists) the partial scores were: Gen Fac $=0.891, \mathrm{Edu}=0.735$, and $\mathrm{Stu}=0.642$; for the second subcomponent (scientific arguments are as valid and respectable as their non-scientific counterparts), the partial scores were: Gen $\mathrm{Fac}=0.806$, $\mathrm{Edu}=0.641$, and $\mathrm{Stu}=0.635$; and third subcomponent (crime-scene and accident-scene investigators use a different type of scientific method to investigate a crime or an accident) the partial scores were: $\mathrm{Gen} \mathrm{Fac}=0.792, \mathrm{Edu}=0.584$, and $\mathrm{Stu}=0.526$. 


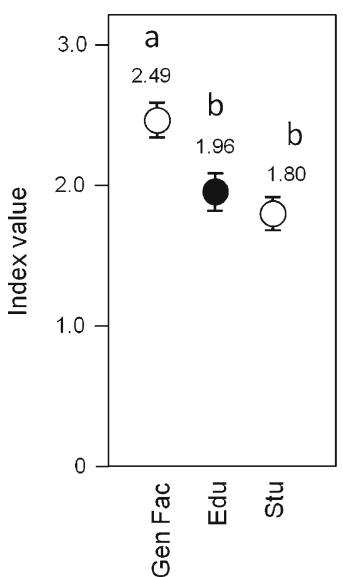

a

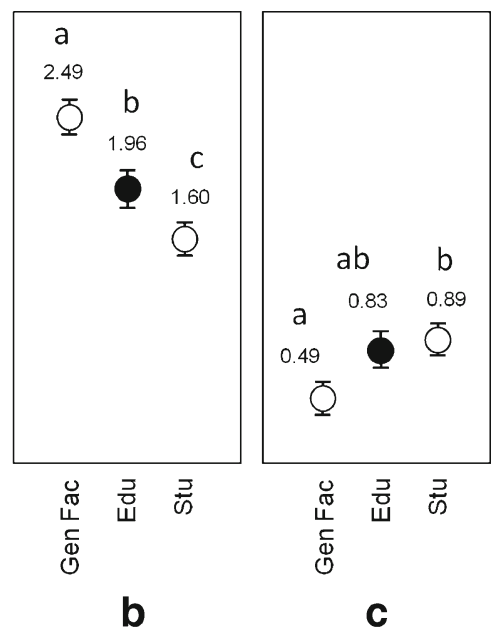

Fig. 11 Understanding of science, evolution, and religiosity indexes of New England general faculty (Gen Fac, white circles, left), educators of prospective teachers (Edu, black circles, center), and college students (Stu, white circles, right). Each index ranges from 0 to 3 (lower to higher levels of understanding of science and evolution, or least to most religious position) as follows: $a$ for the understanding-ofscience index, responders received +1 if they rejected the idea that scientific theories are based on opinions by scientists, +1 if they disagreed with the notion that scientific arguments are as valid and respectable as their nonscientific counterparts, and +1 if they rejected the statement that crime-scene and accident-scene investigators use a different type of scientific method to investigate a crime or an accident; Kruskal-Wallis one-way ANOVA on ranks, $H=89.365, d f=2, P \leq$ 0.001 . $b$ The evolution index, responders received +1 if they rejected the idea that organisms acquire beneficial traits during their lifetimes and then pass on these traits to their descendants, +1 if they disagreed with the notion that during evolution monkeys such as chimpanzees can turn into humans, and +1 if they rejected the statement that the origin of the human mind and consciousness cannot be explained by evolution; Kruskal-Wallis one-way ANOVA on ranks, $H=171.683$, $d f=2, P \leq 0.001 . c$ The religiosity index, responders received +1 if they agreed with the idea that faith in God is necessary for morality, +1 if they accepted the statement that religion is very important in their lives, and +1 if they said they pray daily; Kruskal-Wallis one-way ANOVA on ranks, $H=21.734, d f=2, P \leq 0.001$. Lowercase letters indicate Dunn-test two-tail pair-wise comparisons within groups $P \leq 0.05$. Gen Fac, $n=222 ;$ Edu, $n=53$; and Stu, $n=576$. Error bars are standard errors

Understanding of Evolution Index The general faculty, educators of prospective teachers, and students differed distinctively in their levels of understanding evolution: the educators of prospective teachers had intermediate levels of understanding evolution (Edu EI=1.96) between the general faculty (Gen Fac EI=2.49) and the students (Stu EI= 1.60; Fig. 11; Kruskal-Wallis one-way ANOVA on ranks, $\mathrm{H}=171.683, d f=2, P \leq 0.001)$. Note that each of these three groups were statistically different (Dunn test, two-tail pairwise comparisons $P \leq 0.05$; Fig. 11). The three groups responded distinctively to each of the subcomponents of choice $\mathrm{b}$, question 10 (above), as follows: first subcomponent (organisms acquire beneficial traits during their lifetimes and then pass on these traits to their descendants) the partial scores were: $\mathrm{Gen} \mathrm{Fac}=0.689, \mathrm{Edu}=0.415$, and $\mathrm{Stu}=0.230$; second subcomponent (during evolution monkeys such as chimpanzees can turn into humans) the partial scores were: Gen $\mathrm{Fac}=0.950, \mathrm{Edu}=0.867$, and $\mathrm{Stu}=0.725$; and third subcomponent (the origin of the human mind and consciousness cannot be explained by evolution) the partial scores were: Gen $\mathrm{Fac}=0.851, \mathrm{Edu}=0.679$, and $\mathrm{Stu}=0.642$.

Religiosity Index The general faculty, educators of prospective teachers, and students differed in their levels of religiosity: the educators of prospective teachers had intermediate levels of religiosity (Edu $\mathrm{RI}=0.83$ ) between the general faculty (Gen Fac RI=0.49) and the students (Stu RI=0.89; Fig. 11; Kruskal-Wallis one-way ANOVA on ranks, $\mathrm{H}=$ 21.734, $d f=2, P \leq 0.001$ ), but only the general faculty RI differed statistically from the students' RI (Dunn test twotail pair-wise comparisons $P \leq 0.05$; Fig. 11). The three groups responded distinctively to each of the subcomponents of choice $\mathrm{c}$ in question 10 (above), as follows: first subcomponent (faith in God is necessary for morality), the partial scores were: $\mathrm{Gen} \mathrm{Fac}=0.045$, Edu $=0.075$, and $\mathrm{Stu}=$ 0.246 ; second subcomponent (religion is very important in my life) the partial scores were: $\mathrm{Gen} F \mathrm{Fac}=0.283$, Edu $=0.415$, and $\mathrm{Stu}=0.372$; and third subcomponent (I pray at least once $a$ day) the partial scores were: $\mathrm{Gen} F \mathrm{Fac}=0.166$, Edu $=0.339$, and $\mathrm{Stu}=0.267$.

Associations between Indexes The three groups showed directionality in the association between indexes (Fig. 12). Levels of understanding of science and evolution by the general faculty, educators of prospective teachers, and students decreased with increasing religiosity (i.e., a negative association of variables). In contrast, levels of understanding of evolution increased with increasing understanding of science (i.e., a positive association of variables). The scale at which the SI and EI indexes decreased as a function of increasing RI was in accordance with the high levels of understanding of science/evolution-and low religiosity-by the general faculty in respect to the intermediate and low levels of understanding of science/evolution-and high religiosity-by the educators of prospective teachers and the students, respectively (first and second rows, Fig. 12). Analogously, the scale at which the EI index increased as a function of SI was in accordance with the high understanding of science/evolution by the general faculty and the intermediate and low levels of understanding of science by the educators of prospective teachers and the students, respectively (third row, Fig. 12). Note the following pattern in Fig. 12: in the context of SI versus RI comparisons, the highest to lowest levels of understanding of science by the general faculty (Gen Fac SI $=2.59-2.0 ; 69.8-3.2 \%$ of responders; index $R^{2}=0.964, P=0.009$; Fig. 12a), educators of prospective teachers (Edu SI $=2.07-1.0 ; 52.8-7.5 \%$ of responders; index $R^{2}=0.740, P=0.069$; Fig. $12 \mathrm{~b}$ ), and students 
a

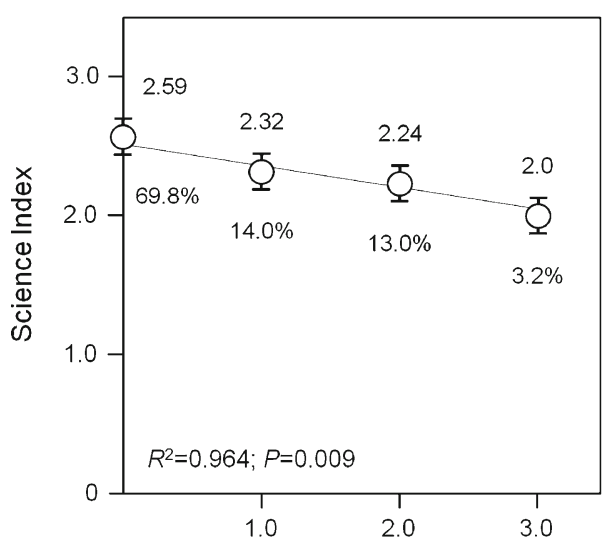

Religiosity Index

d

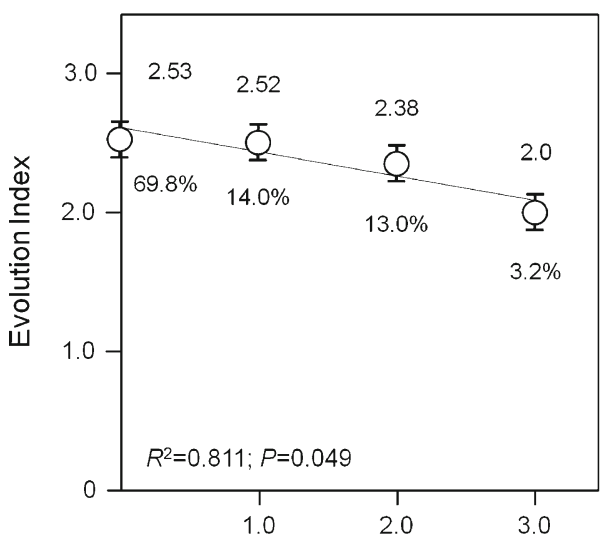

Religiosity Index

g

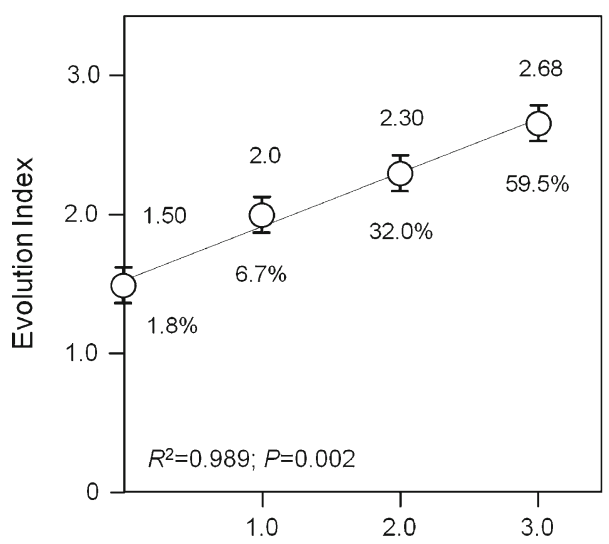

Science Index b $\quad$ Edu

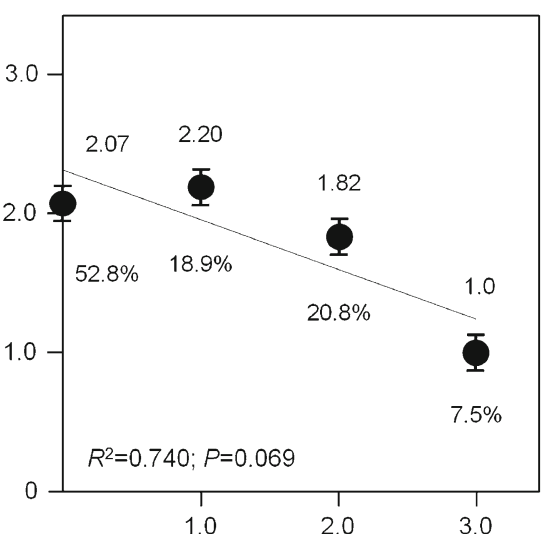

Religiosity Index

e

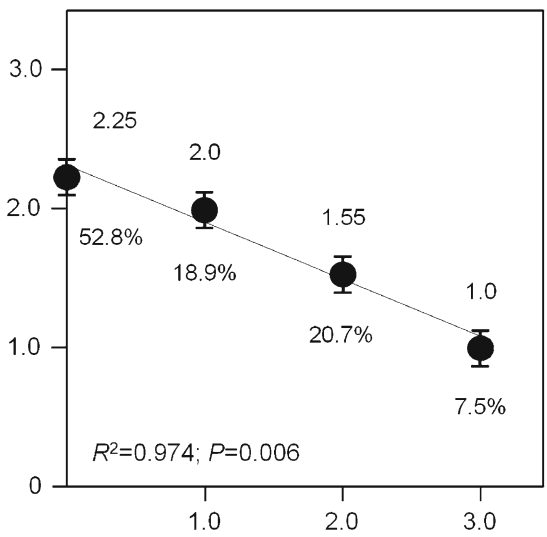

Religiosity Index

h

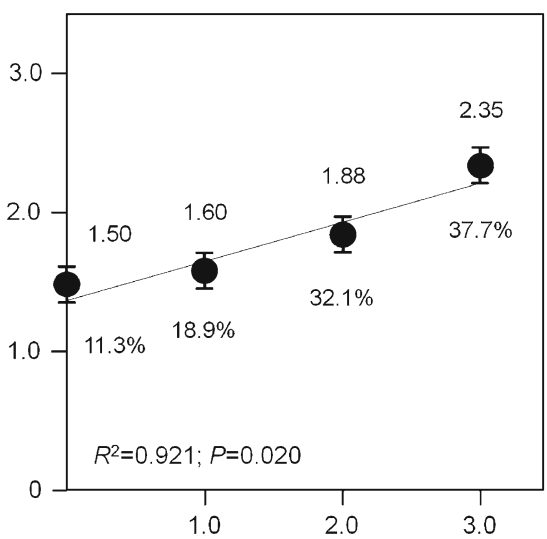

Science Index c Stu

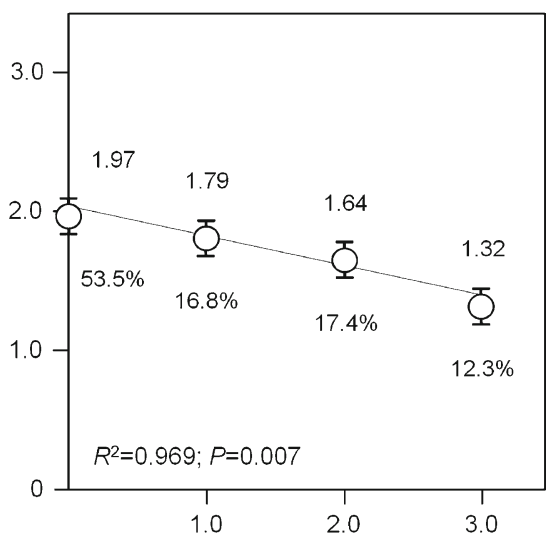

Religiosity Index

f

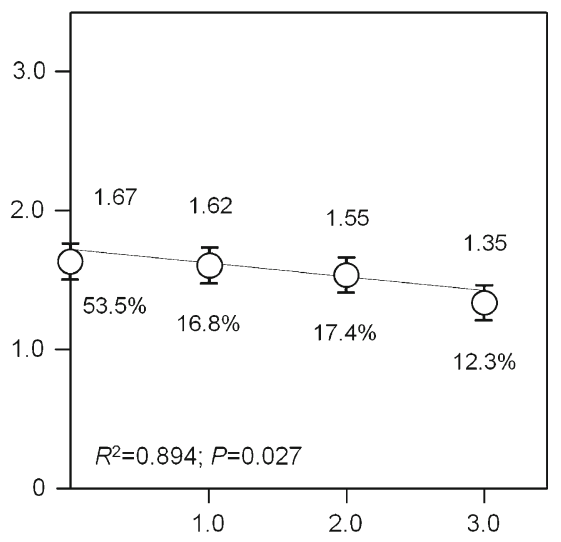

Religiosity Index

i

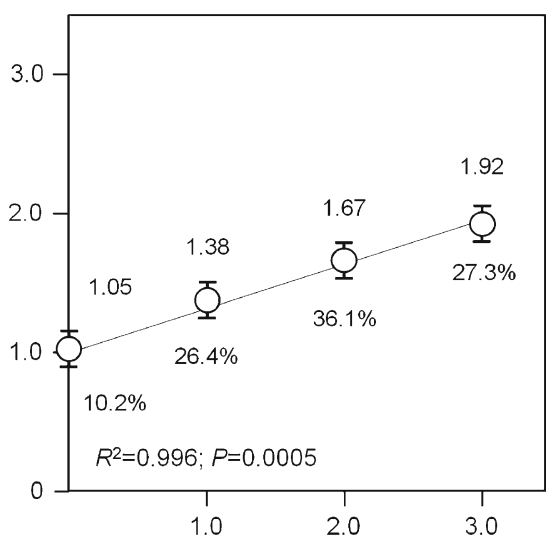

Science Index
Fig. 12 Association between understanding of science, evolution, and religiosity indexes of New England general faculty (Gen Fac, white circles, left), educators of prospective teachers (Edu, black circles, center) and college students (Stu, white circles, right). The linear regressions depict the association between the 0-to-3 levels of: first row, science index versus religiosity index; second row, evolution index versus religiosity index; and third row, evolution index versus science index for each of the subpopulations of responders (i.e., Gen Fac: $a, d, g ; E d u: b, e, h$; and Stu: $c, f, i)$; the inverse association between level of understanding of science/ evolution and level of religiosity (first and second rows), as well as the direct association between level of understanding of evolution and level of understanding of science (third row) are evident. Numbers above and below regression lines correspond to index values and percent of responders per data point, respectively. Linear regressions one tail: $a, R^{2}=0.964$, $P=0.009 ; b, R^{2}=0.740, P=0.069 ; c, R^{2}=0.969, P=0.007 ; d, R^{2}=0.811$, $P=0.049 ; e, R^{2}=0.974, P=0.006 ; f, R^{2}=0.894, P=0.027 ; g, R^{2}=0.989$, $P=0.002 ; h, R^{2}=0.921, P=0.020 ;$ and $i, R^{2}=0.996, P=0.0005$. Gen Fac, $n=222$; Edu, $n=53$; and Stu, $n=576$. Error bars are standard errors 
(Stu SI $=1.97-1.32 ; 53.5-12.3 \%$ of responders; index $R^{2}=$ $0.969, P=0.007$; Fig. $12 \mathrm{c}$ ) corresponded to the lowest to highest levels of religiosity ( $\mathrm{RI}=0.0-3.0)$ in each group, respectively. In the context of EI versus RI, the highest to lowest levels of understanding of evolution by the general faculty (Gen Fac EI $=2.53-2.0 ; 69.8-3.2 \%$ of responders; index $R^{2}=0.811, P=0.049$; Fig. 12d), educators of prospective teachers (Edu EI $=2.25-1.0 ; 52.8-7.5 \%$ of responders; index $R^{2}=0.974, P=0.006$; Fig. 12e), and students (Stu $\mathrm{EI}=$ $1.67-1.35 ; 53.5-12.3 \%$ of responders; index $R^{2}=0.894, P=$ 0.027 ; Fig. 12f) corresponded to the lowest to highest levels of religiosity ( $\mathrm{RI}=0.0-3.0)$ in each group, respectively. And, in the context of EI versus SI, the lowest to highest levels of understanding of evolution by the general faculty (Gen Fac $\mathrm{EI}=1.50-2.68 ; 1.8-59.5 \%$ of responders; index $R^{2}=0.989$, $P=0.002$; Fig. $12 \mathrm{~g}$ ), educators of prospective teachers (Edu $\mathrm{EI}=1.50-2.35 ; 11.3-37.7 \%$ of responders; index $R^{2}=0.921$, $P=0.020$; Fig. $12 \mathrm{~h}$ ), and students (Stu $\mathrm{EI}=1.05-1.92 ; 10.2-$ $27.3 \%$ of responders; index $R^{2}=0.996, P=0.0005$; Fig. 12i) corresponded to the lowest to highest levels of understanding of science ( $\mathrm{SI}=0.0$ to 3.0$)$ in each group, respectively.

\section{Discussion}

To facilitate the discussion of the data, below we round up the values and discuss them in the context of generalizations and broad patterns:

\section{Views about Evolution, Creationism, and ID}

The educators of prospective teachers consistently held intermediate positions about evolution, creationism and intelligent design in respect to the general faculty and the students, as follows: $96 \%$ of the general faculty versus $86 \%$ of the educators of prospective teachers versus $71 \%$ of the students supported the exclusive teaching of evolution in science classes, and only $4 \%$ of the general faculty versus $14 \%$ of the educators of prospective teachers versus $29 \%$ of the students favored equal time to evolution, creationism and intelligent design (Fig. 1); $92 \%$ of the general faculty versus $82 \%$ of the educators of prospective teachers versus $50 \%$ of the students perceived ID as either not scientific and proposed to counter evolution based on false claims or as religious doctrine consistent with creationism (combined values choices $a+b$, Fig. 2). Only $8 \%$ of the general faculty versus $18 \%$ of the educators of prospective teachers versus $40 \%$ of the students had either no opinion about ID, considered it a scientific alternative to evolution and of equal scientific validity among scientists, or thought of ID as a scientific theory about the origin of life on Earth (combined values choices $\mathrm{c}+\mathrm{d}+\mathrm{e}$, Fig. 2). Although the general faculty and the educators of prospective teachers had a clearer understanding of ID than the students (Gen Fac and Edu were statistically similar; Fig. 2), it is of concern that one in ten general faculty, one in five educators of prospective teachers, and one in two students were unaware of the nature of ID or considered it a legitimate scientific proposal.

Most of the general faculty $(97 \%)$ and many of the educators of prospective teachers $(81 \%)$ and the students $(76 \%)$ preferred factual explanations about the origin of life on Earth and its place in the universe (choice a, Fig. 3). Although only one in 30 general faculty thought that evolution and creationism are in harmony, one in five educators of prospective teachers, and one in four students favored this position (choice b, Fig. 3). Interestingly, $96 \%$ of the general faculty, educators of prospective teachers, and students preferred science courses where evolution is discussed comprehensively and humans are part of it (mean combined values choice a, Fig. 4), and $76 \%$ of all responders had no problem with either instructors including questions concerning evolution in exams or answering questions concerning evolution (mean combined values choice a, Fig. 5). In fact, one in every four responders considered that science exams should always include some questions concerning evolution (choice b, Fig. 5).

Most of the general faculty (94\%) and many of the educators of prospective teachers (75\%) indicated they accept evolution and express it openly regardless of others' opinions; only $63 \%$ of the students agreed with this position. Although only one in about 20 general faculty either did not comment on this issue or said they accept evolution privately (choices b, c, Fig. 6), one in four educators of prospective teachers and one in three students held these positions. Indeed, educators of prospective teachers hesitated to embrace evolution. Note that only $71 \%$ of them thought that evolution is definitely true and $29 \%$ considered it to be probably true (Fig. 7), placing between the general faculty (definitely true $82 \%$; probably true $18 \%$ ) and the students (definitely true $58 \%$; probably true $42 \%$; Fig. 7 ).

\section{Views about the Evolutionary Process}

The educators of prospective teachers held an intermediate level of understanding of the evolutionary process in respect to the general faculty and the students. In some cases, their opinions were statistically similar to the students' and differed from those of the general faculty, as follows: $86 \%$ (mean value) of the general faculty, educators of prospective teachers, and students agreed with a comprehensive definition of evolution as a gradual process by which the universe changes, [which] includes the origin of life, its diversification and the synergistic phenomena resulting from the interaction between life and the environment. And 69\% (mean value) correctly rejected the definition that evolution is a random process by which life originates, changes, and ends 
accidentally in complex organisms such as humans (choices a, d, Fig. 8). The general faculty correctly rejected (89\%) the notion of "purpose" and "goal toward humanity" in evolution (choice b, Fig. 8) and also the misconception that humans have evolved from chimpanzees (rejection 94\%, choice c, Fig. 8) or the possibility of Lamarckian inheritance of acquired traits (rejection only $69 \%$, choice e, Fig. 8). In contrast, only $60 \%, 87 \%$, and $42 \%$ of the educators of prospective teachers rejected these statements, respectively (choices b, c, e, Fig. 8). Their views were statistically similar to the students' regarding these choices.

The level of understanding of how evolution works varied among the general faculty, educators of prospective teachers, and students. All agreed that evolution relies on common ancestry (93\%, mean choice a, Fig. 9) and that humans are apes (64\%, mean choice b, Fig. 9); however, one in four general faculty, one in two educators of prospective teachers, and one in three students did not know that humans are close relatives to chimpanzees, bonobos, gorillas, and orangutans (choice b, Fig. 9). Eighty-nine percent of the general faculty, educators of prospective teachers, and students (mean values choice c, Fig. 9) knew that the hominid fossil record is rich enough for scientists to conclude that humans have evolved from ancestral forms, but one in five general faculty and one in three educators of prospective teachers and students (mean) believed, incorrectly, that the origin of the human mind cannot be explained by evolution (choice d, Fig. 9). Indeed, one in five general faculty and almost half of the educators of prospective teachers and students (mean) thought, erroneously, that the universe, our solar system and planet Earth are finely tuned to embrace human life (choice e, Fig. 9). The latter (i.e., the anthropic principle; Stenger 2011) is a powerful illusion and a byproduct of the self-referent human mind engaged in examining the cosmos. Moreover, the diversity of successful adaptations in nature gives the impression that the environment perfectly matches them. In reality, it is life that "matches" the always-changing environments (Paz-yMiño-C and Espinosa 2011a).

\section{Responders' Religiosity}

Interestingly, the general faculty, educators of prospective teachers, and students showed statistically comparable responses in choice $\mathrm{b}$ of question 10 (above): $\approx 36 \%$ of them (mean) considered religion to be very important in their lives. But they differed in choices a and $\mathrm{c}$ of question 10 : one in 16 (mean) educators of prospective teachers and general faculty believed that faith in God is necessary for morality, in contrast to one in four students (Fig. 10); and one in three (mean) educators of prospective teachers and students said they pray daily, in contrast to one in six general faculty (Fig. 10).
Despite the percentile statistical similarity ( $\approx 36 \%$, above) among the general faculty, educators of prospective teachers, and students who considered religion [to be] very important in their lives, the independent $41.5 \%$ agreement with this statement by the educators of prospective teachers is higher than the $29 \%$ by the general faculty (Fig. 10) and among the highest reported for Ph.D.-educated audiences. For example, $33 \%$ of American scientists $(n=2,533)$ say they believe in God (The Pew Research Center for the People \& the Press 2009), in contrast to $12 \%$ of "professional evolutionary scientists" ( $n=149$ members of North American, European, UK, and other countries' National Academies of Sciences; Graffin and Provine 2007) and 7\% of members of the U.S. National Academy of Science $(n=$ 260) who believe in a personal God (Larson and Witham 1998). Two studies ( $n=1,646$, Ecklund and Scheitle 2007; $n=1,417$, Gross and Simmons 2009) have documented that $\approx 30 \%$ of the American professoriate (ca. 630,000 faculty teaching full time at colleges and universities) is religious across institutions and fields, highlighting that researchers in the natural sciences (physics, biology) are less religious than their social sciences counterparts (sociology, economics, history, except psychology); our sample of educators of prospective teachers was indeed highly religious. Responders' religiosity is discussed beyond the percentile description and in more depth below, when addressing the RI.

Understanding of Science, Evolution, and Religiosity Indexes

The educators of prospective teachers consistently held intermediate levels of understanding science, the evolutionary process, and religiosity in respect to the general faculty and the students (Fig. 11), as follows: the general faculty were the most knowledgeable about science and evolution and the least religious (Gen Fac: $\mathrm{SI}=2.49, \mathrm{EI}=2.49$, and $\mathrm{RI}=0.49$; Fig. 11). The educators of prospective teachers reached lower science and evolution - but higher religiosity — indexes than the general faculty (Edu: $\mathrm{SI}=1.96, \mathrm{EI}=1.96$, and $\mathrm{RI}=0.83$; Fig. 11); and the students were the least knowledgeable about science and evolution and the most religious (Stu: $\mathrm{SI}=1.80, \mathrm{EI}=1.60$, and $\mathrm{RI}=0.89$; Fig. 11). Understanding of science and evolution were inversely correlated with level of religiosity, and understanding of evolution increased with increasing science literacy (Fig. 12). The SI, EI, and RI index patterns reported here are in accordance with the proposal of various scholars (Bishop and Anderson 1990; Downie and Barron 2000; Trani 2004; Paz-y-Miño-C and Espinosa 2009a, b, 2011a, b; but see Miller et al. 2006; Nadelson and Sinatra 2009) that the interaction between science/evolution literacy and level of religiosity determine an individual's acceptance of evolution, which is corroborated by additional evidence compiled by this study: (1) the 
overall high and open acceptance of evolution by the general faculty (94\%), intermediate by the educators of prospective teachers $(75 \%)$, and low by the students $(63 \%$, Fig. 6); and (2) the observation that $82 \%$ of the general faculty (high), $71 \%$ of the educators of prospective teachers (intermediate), and $58 \%$ of the students (low) thought that evolution is definitely true (above; Fig. 7).

Various studies have detected inverse correlation between religiosity/belief and acceptance of evolution (Miller et al. 2006; The Gallup Poll 2008, 2009, 2010; Nadelson and Sinatra 2009), and a positive association between evolution acceptance and scientific literacy, particularly genetics (Miller et al. 2006). However, there is discrepancy about the association between general educational attainment and attitudes toward evolution (Miller et al. 2006; Pigliucci 2007; Nehm and Schonfeld 2007). It is important to emphasize that the religiosity indexes of our samples of general faculty and the educators of prospective teachers/students were three and about two times below the U.S. national score RI=1.40, $n=2,026$ (The Pew Global Attitudes Project 2007), respectively, but that only the New England general faculty had a level of religiosity comparable to that of the general public in Western Europe, the lowest worldwide (The Pew Global Attitudes Project 2007; Paz-y-Miño-C and Espinosa 2011a). Our educators of prospective teachers sampled here were statistically as religious as the students (Fig. 11) and more religious than the Canadian general public (RI=0.72; The Pew Global Attitudes Project 2007), whose overall acceptance of evolution is $58 \%$, although $63 \%$ of East Coast Canadians accept evolution $(n=1,007$; Angus Reid Strategies 2008), which is comparable to 59\% of their East Coast American counterparts (The Pew Research Center for the People and the Press 2005).

\section{Characterizers of acceptance of evolution in the U.S.}

Public acceptance of evolution in the U.S. correlates with level of education, increasing from the high school (20/ $21 \%)$, to the some college $(32 / 41 \%)$, college graduate $(52 /$ $53 \%)$, post-graduate $(65 / 74 \% ; n=\mathrm{NA} / 1,018$; Brumfiel 2005; The Gallup Poll 2009), and university professor levels (97\%, Paz-y-Miño-C and Espinosa 2011a, this study; choices a+c, Fig. 6). The average acceptance of evolution by the U.S. general public is 35-40\% (Brumfiel 2005; Miller et al. 2006), which coincides with the population attaining only some college education (above). Although $88 \%$ (open + private acceptance of evolution; choices a $+c$, Fig. 6) of the New England educators of prospective teachers sampled in this study accepted evolution, their score was below the general faculty $(97 \%$, choices a+c, Fig. 6) and comparable to the students' $(83 \%$, choices a $+c$, Fig. 6$)$, the latter higher than their national counterparts (above). Only the U.S. postgraduates and our samples of New England college students, educators of prospective teachers, and general faculty have levels of acceptance of evolution comparable to or higher than the general public in other industrialized and prosperous nations like Iceland, Denmark, Sweden, France, Japan, and the UK $\approx 75-85 \%$; Miller et al. 2006; see detailed discussion in Paz-y-Miño-C and Espinosa 2011a).

Opposition to evolution in the U.S. resides in specific variables (Paz-y-Miño-C and Espinosa 2011a, b): religious beliefs, pro-life beliefs, and political ideology account for most of the variance against evolutionary views (total nine independent variables), which differ distinctly between the U.S. $\left(R^{2}=0.46\right.$ total effects $)$ and Europe $\left(R^{2}=0.18\right.$ total effects; Miller et al. 2006; Miller and Pennock 2008; see The Pew Forum on Religion \& Public Life 2008 for detailed statistics on the relationship between religious affiliations and pro-life beliefs, political ideology, and evolution); among U.S. educational professionals, decrease in both evolution acceptance and knowledge correlates with increase in religious commitment $(n=337$; Nadelson and Sinatra 2009); conservative Republicans in the U.S. accept evolution less than progressive liberals and independents ( $30 \%$ versus $60 \%$, respectively, $n=1,007$; The Gallup Poll 2007); and frequency of religious practices correlates negatively with acceptance of evolution: $24 \%$ among weekly churchgoers versus $71 \%$ for seldom or never $(n=1,007$; The Gallup Poll 2007).

We have previously postulated (Paz-y-Miño-C and Espinosa 2011a) that if attitudes toward evolution by both the general public and highly educated audiences such as university professors ultimately correlate with understanding of science/evolution and religiosity/political ideology (positive and negative association of variables, respectively; data above), it follows that robust science education combined with vigorous public debate - where scientific knowledge versus popular belief are constantly discussed - should increase acceptance of naturalistic rationalism and decrease the negative impact of creationism and ID on "society's evolution literacy." We acknowledge, however, that societal interactions between science and ideology are complex, multi-factorial, variable in a spatiotemporal context, and subject to public policy, demographics, law and socio-economic change (Lerner 2000; Moore 2002, 2004; Gross et al. 2005; Apple 2008; Miller and Pennock 2008; Berkman and Plutzer 2009; Ecklund and Park 2009; Padian and Matzke 2009; Matzke 2010; Wexler 2010; Paz-y-Miño-C and Espinosa 2011a, b).

Why do the highly trained educators of prospective teachers (87\% Ph.D./doctorate holders) hesitate to embrace evolution or have lower acceptance of evolution than the general faculty ( $93 \%$ Ph.D./doctorate holders)? The negative feedback among variables reported in this study (i.e., science/evolution versus religiosity), plus the U.S. trends in acceptance of evolution as function of academic level (above), help us address this question: (1) the higher the 
level of understanding science/evolution, the lower the level of religiosity among all responders (Figs. 11 and 12); (2) the higher the level of understanding of science, the higher the level of understanding of evolution in all groups (Fig. 12); and (3) the higher the level of education, the higher the acceptance of evolution and the lower the religiosity (compiled national data, Brumfiel 2005; The Gallup Poll 2009, 2010; Paz-y-Miño-C and Espinosa 2009a, b, 2011a, this study). Because we assume that the Ph.D.- or doctoraltraining levels in pedagogy (i.e., the specialization of the educators of prospective teachers) or in other academic fields (=the general faculty) are analogously rigorous in the U.S., we conclude that the hesitation to fully embrace evolution by the educators of prospective teachers is inherent to their deficient understanding of science/evolution and high religiosity (Figs. 10, 11, and 12). Although differences in attitudes toward evolution by professors in diverse fields and geographic regions of the U.S. are conceivable, our sample of the New England general faculty generated unambiguous responses (Gen Fac: 94/3\% open/private acceptance of evolution and $3 \%$ no opinion) in contrast to the cautious views held by the educators (Edu: $75 / 13 \%$ open/ private acceptance of evolution and $13 \%$ no opinion; Fig. 6).

How can the educators of prospective teachers strengthen their own literacy in science and evolution and make a significant impact on the literacy of their "academic progeny," the future teachers? We suggest: (1) Applying equal rigor to the training in pedagogy and science/evolution; the educators of prospective teachers should reach comparable levels of understanding science/evolution and accepting evolution to those of the general-faculty. There are reputable online courses in evolution available to all audiences (e.g., University of Arizona, see references), and the National Science Teachers Association, National Association of Biology Teachers, National Science Foundation, Smithsonian National Museum of Natural History, The Society for the Study of Evolution, National Academies of Sciences, American Museum of Natural History, or the Understanding Evolution of the University of California Berkeley Museum of Paleontology offer impressive online resources specific for educators (see links in references). (2) Dialoging with the science faculty at their own institutions and agreeing to fortify the on-the-jobscience/evolution training of the educators of prospective teachers, as well as of the students enrolled in education programs. The ubiquitous disconnect between the education departments and the rest of the academic fields at U.S. colleges and universities is concerning, and it requires immediate interaction between the educators and the general faculty (see Paz-y-Miño-C and Espinosa 2011a). (3) Educating themselves about the "antievolution wars" (Ruse 2001; Pigliucci 2007; Berkman and Plutzer 2009; Branch et al. 2010) and participating decisively in the pro-teaching-of-evolution movement. In this area of public discourse, our sample of educators of prospective teachers also placed below the standards held by the general faculty: $85 \%$ of the educators of prospective teachers versus $91 \%$ of the general faculty were very concerned (Edu 44\% versus Gen Fac 64\%) or somewhat concerned (Edu $41 \%$ versus Gen Fac 27\%) about the controversy over evolution versus creationism versus ID and its implications for science education (data, this study). It is crucial that the educators of prospective teachers lead the institutional (their own colleges and universities), regional and national strategies to secure proper science/evolution education among the prospective teachers who earn degrees under their guidance. As university professors, the educators of prospective teachers are less vulnerable to institutional or societal reprisal for leading the teaching of evolution than their academic progeny of young teachers. Note that $43 \%$ of school instructors are willing to dedicate "equal time" to science and ID (National Science Foundation 2006), and 30\% say they have been pushed to deemphasize or omit evolution or evolution-related topics from their curriculum due to pressure coming from students and parents (National Science Teachers Association 2005). The educators of future educators are as responsible for sponsoring proper science/evolution training to the prospective teachers as the latter are for acquiring and communicating that knowledge to their students. (4) Study the legal protection that guarantees proper science/evolution education at all academic levels and make this information available to prospective teachers as part of their regular training. The National Center for Science Education maintains a comprehensive website (see references) with information and resources for schools, parents and concerned citizens working to keep evolution in public school science education (see also Moore 2004); its link "taking action" is particularly valuable for educators of future educators and the prospective teachers they mentor. (5) Implement curriculum reforms at their education departments and institutions to fortify science training of prospective teachers. Highereducation programs in science, particularly biology, are fundamental to integrating evolution into the academic backgrounds of prospective teachers (Paz-y-Miño-C and Espinosa 2009a, b, 2011a). Note that school teachers in the U.S. rely on poor-toexcellent evolution state education standards that guide their teaching practices (Mead and Mates 2009; for a historical account of this type of assessments, see Moore 2002; Lerner $2000,2006)$ and that when unprepared in science/evolution their personal opinions influence the quality of schooling more than states' guidelines: $14-69 \%$ of school teachers $(n=15$ states in the U.S.) question or reject evolution and teach supernatural causation (Moore 2002), and 13\% explicitly advocate creationism and ID in classes (Berkman and Plutzer 2011). (6) Poll in-campus variations in attitudes toward science and evolution among the educators of future educators, the prospective teachers they mentor, and the general faculty, and coordinate immediate responses to the emerging antievolutionism in the U.S. campuses (Paz-y-Miño-C and Espinosa 2011a; 
see Evolution Literacy University of Massachusetts Dartmouth in references). Contrary to the assumption that skepticism toward creationists views predominates in academia, this study and others (Ecklund and Scheitle 2007; Gross and Simmons 2009; Ecklund and Long 2011; Paz-y-Miño-C and Espinosa 2011a) demonstrate that U.S. university professors, even at prestigious research institutions, increasingly say they embrace religiosity, a factor negatively correlated with acceptance of evolution (Miller et al. 2006; The Gallup Poll 2007, 2008, 2009, 2010; Nadelson and Sinatra 2009; this study). It is, therefore, conceivable to forecast a decline in acceptance of evolution by all faculty (Paz-y-Miño-C and Espinosa 2011a), and particularly by the educators of prospective teachers whose religiosity is high (this study), but these predictions need longitudinal verification. (7) Cosponsor with the general faculty in- and off- campus lecture series, workshops and debates to examine antievolution phenomena, learn about the obstacles raised by school boards on the science school curriculum, and orient other educators of future educators and prospective teachers on how to communicate modern science to all (Paz-y-Miño-C and Espinosa 2009b, 2011a). Workshopdiscussion modules on why evolution matters can be particularly effective when organized for educators of future educators and prospective teachers (see exemplar case in Johnson et al 2009). (8) Pursue participation in and organization of "town halls for educators of prospective teachers" to discuss issues related to the controversy evolution versus creationism versus ID (similar to Paz-y-Miño-C and Espinosa 2011a). Surprisingly, only $24 \%$ of the U.S. faculty is aware of these meetings, which are often organized around the nation; the detachment of all professors from the public is concerning: $48 \%$ say they talk with non-academicians occasionally (The Pew Research Center for the People \& the Press 2009). (9) Participate in and sponsor multidisciplinary conferences (anthropology, biology, education, ethics, history, law, philosophy, political science, social psychology, religious studies) to learn the theoretical and practical aspects of civil action to counter antievolution campaigns, anti-intellectualism tendencies, and pro creationism and ID agendas (Young and Edis 2004; Petto and Godfrey 2007; Coalition of Scientific Societies 2008; Williams 2009). And (10) monitor the antievolution movements that grow strong among misinformed citizens, vary in impact geographically, and benefit from the disconnect between highly educated audiences, like educators of prospective teachers/general faculty, and society (Paz-y-Miño-C and Espinosa 2011a; note that the National Center for Science Education monitors the antievolution movement, see link in references). The regional differential acceptance of evolution in the U.S. (i.e., Northeast, 59\%; Northwest, 57\%; Midwest, 45\%; South, 38\%; The Pew Research Center for the People \& the Press 2005) suggests that pro-evolution campaigns require strategies compatible with local idiosyncrasies (Paz-y-Miño-C and Espinosa 2011a); the educators of prospective teachers must take the lead in conceptualizing and strategizing the civil discourse and societal action to ensure internationally competitive science/evolution literacy in the U.S.

\section{Significance of this Study}

This is the first study to explore statistically and comparatively the views of a representative sample of 62 highly trained educators of prospective teachers (87\% Ph.D./ doctorate holders who work in 32 specializations) in respect to 244 general faculty $(93 \%$ Ph.D./doctorate holders in 40 disciplines), affiliated with 35 academic institutions (public, private, and religious), widely distributed geographically in New England (states of Connecticut, Maine, Massachusetts, New Hampshire, Rhode Island, and Vermont), and 827 college students (subsample of the 35 institutions) who were polled in three areas: (1) the controversy over evolution versus creationism versus ID, (2) their understanding of how science/evolution works, and (3) their religiosity. Our survey was conducted in one of the most progressive and intellectual regions in the U.S., where public acceptance of evolution is the highest nationwide (59\%). The educators of prospective teachers consistently held intermediate positions about the three surveyed areas (above) in respect to the general faculty and the students. Understanding of science and evolution correlated inversely with level of religiosity, and understanding of evolution increased with increasing science literacy. The general faculty were the most knowledgeable about science/evolution and the least religious, while the educators reached lower science/evolution-but higher religiosity - levels than the general faculty; the educators' views were statistically comparable to the students' who were the least knowledgeable about science/evolution and the most religious. The patterns of hesitant support to evolution by the educators of prospective teachers, due to a deficient understanding of science and the evolutionary process, combined with high religiosity, are concerning since these educators are responsible for mentoring prospective teachers. Adequate training in science/evolution is indispensable among all education specialists to minimize the negative impact of creationism and ID on the U.S. educational system.

Acknowledgments We thank the New England general faculty, educators of prospective teachers, and students at UMassD, RWU, PC, and SRU who participated in the study. Charlotte O'Driscoll and Lauren Murray compiled part of the email data base of New England educators of prospective teachers and general faculty, respectively; Joyce Rosinha coordinated the email distribution of surveys to students at UMassD; Nicanor Austriaco and the BioSociety supported this initiative at PC, Kristine Hendrickson at SRU, and Patricia Kennedy and Patricia Pimental at RWU. Tammy Silva, Gregory Rogers, Kristen Procopio, Julie Coccia, and Frederick Promades provided part of the data to build Table S2. The Human Subjects/Institutional Review Boards at UMassD, RWU, PC and SRU approved the 
protocols. G. Paz-y-Miño-C is supported by the UMassD Office of Faculty Development (Innovation in Teaching Awards AY0910 and Undergraduate Research Grants F09) and A. Espinosa by NIH-NCRR grant \#2 P20RR16457-11. An anonymous reviewer provided insightful comments that helped us improve the manuscript.

\section{References}

American Museum of Natural History. http://www.amnh.org/learn/ evolution; 2011

Angus Reid Strategies. Canadians believe human beings evolved over millions of years. http://www.angus-reid.com/wp-content/ uploads/archived-pdf/2008.08.05 Origin.pdf; 2008.

Apple MW. Evolution versus creationism in education. Educ Pol. 2008;22:327-35.

Berkman MB, Plutzer E. Scientific expertise and the culture war: public opinion and the teaching of evolution in the American states. Perspect Polit. 2009;7:485-99.

Berkman MB, Plutzer E. Evolution, creationism, and the battle to control America's classrooms. New York: Cambridge University Press; 2010.

Berkman MB, Plutzer E. Defeating creationism in the courtroom, but not in the classroom. Science. 2011;331:404-5.

Berkman MB, Pacheco JS, Plutzer E. Evolution and creationism in America's classrooms: a national portrait. PLoS Biol. 2008;6:920-4

Bishop BA, Anderson CW. Student conceptions of natural selection and its role in evolution. J Res Sci Teach. 1990;27:415-27.

Branch G, Scott EC, Rosenau J. Dispatches from the evolution wars: shifting tactics and expanding battlefields. Annu Rev Genom Hum Genet. 2010;11:317-38.

Brumfiel G. Who has designs on your students' minds? Nature. 2005;434:1062-5.

Coalition of Scientific Societies. Evolution and its discontents: a role for scientists in science education. FASEB J. 2008;22:1-4.

Cornish-Bowden A, Cárdenas ML. The threat from creationism to the rational teaching of biology. Biol Res. 2007;40:113-22.

Coyne JA. Why evolution is true. New York: Viking; 2009.

Dawkins R. The greatest show on earth: the evidence for evolution. New York: Free Press; 2009.

Donnelly LA, Boone WJ. Biology teachers' attitudes toward and use of Indiana's evolution standards. J Res Sci Teach. 2007;44:236-57.

Downie JR, Barron NJ. Evolution and religion: attitudes of Scottish first year biology and medical students to the teaching of evolutionary biology. J Biol Educ. 2000;34:140-6.

Ecklund EH, Scheitle CP. Religion among academic scientists: distinctions, disciplines, and demographics. Soc Probl. 2007;54:289-307.

Ecklund EH, Park JZ. Conflict between religion and science among academic scientists? J Sci Stud Relig. 2009;48:276-92.

Ecklund EH, Long E. Scientists and spirituality. Sociol Relig. 2011. doi:10.1093/socrel/srr003.

Evolution Literacy University of Massachusetts Dartmouth. http:// pazyminolevolutionliteracy.blogs.umassd.edu/; 2011.

Forrest B. It's déjà vu all over again: the intelligent design movement's recycling of creationist strategies. Evolution: Education and Outreach. 2010;3:170-82.

Forrest BC, Gross PR. Biochemistry by design. Trends Biochem Sci. 2007a;32:301-10

Forrest B, Gross PR. Creationism's Trojan Horse: the wedge of intelligent design. New York: Oxford University Press; 2007b.

Graffin GW, Provine WB. Evolution, religion and free will. Am Sci. 2007:95:294-7.

Gross N, Simmons S. The religiosity of American college and university professors. Sociol Relig. 2009;70:101-29.
Gross PR, Goodenough U, Haack S, Lerner LS, Schwartz M, Schwartz $\mathrm{R}$. The state of state science standards. Washington DC: Thomas B. Fordham Institute; 2005.

Groves RM, Fowler FJ, Couper MP, Lepkowski JM, Singer E, Tourangeau R. Survey methodology. Hoboken New Jersey: Wiley; 2009

Hokayem H, BouJaoude S. College students' perceptions of the theory of evolution. J Res Sci Teach. 2008;45:395-419.

Johnson JB, Adair M, Adams BJ, Fairbanks DJ, Itamura V, Jeffrey DE, Merrell D, Ritter SM, Tolman RR. Evolution Education in Utah: a state office of education-university partnership focuses on why evolution matters. Evolution: Education and Outreach. 2009;2:349-58.

Kitzmiller et al. versus Dover Area School District et al. http://www. pamd.uscourts.gov/kitzmiller/kitzmiller_342.pdf; 2005.

Krauss LM. Cosmic evolution. Evolution: Education and Outreach. 2010;3:193-7.

Larson EJ, Witham L. Leading scientists still reject God. Nature. 1998;394:313.

Lerner LS. Good science, bad science: teaching evolution in the States. Washington DC: The Thomas B. Fordham Foundation; 2000.

Lerner LS. Good, bad, and lots of indifferent: the state of State K-12 science standards and the fate of US science education. Freethought Today, 23, Freedom from Religion Foundation Inc. http://www.ffrf.org/publications/freethought-today/articles/GoodBad-and-Lots-of-Indifferent-The-State-of-State-K-12-ScienceStandards-/; 2006.

Matzke NJ. The evolution of creationist movements. Evolution: Education and Outreach. 2010;3:145-62.

Mayr E. What evolution is. New York: Basic Books; 2001

Mead LS, Mates A. Why science standards are important to a strong science curriculum and how states measure up. Evolution: Education and Outreach. 2009;2:359-71.

Miller KR. Falling over the edge. Nature. 2007;447:1055-6.

Miller KR. Only a theory: evolution and the battle for America's soul. New York: Viking Penguin; 2008.

Miller JD, Pennock RT. Science education and religion in America in the 21st century: holding the center. In: Keysar A, Kosmin BA, editors. Secularism and science in the 21st century. Harford: Institute for the Study of Secularism in Society and Culture; 2008.

Miller JD, Scott EC, Okamoto S. Public acceptance of evolution. Science. 2006;313:765-6.

Moore R. Teaching evolution: do state standards matter? Bioscience. 2002;52:378-81.

Moore R. How well do biology teachers understand the legal issues associated with the teaching of evolution? Bioscience. 2004;54:860-5.

Moore R. What are students taught about evolution? McGill Journal of Education. 2007;42:177-87.

Moore R, Kraemer K. The teaching of evolution \& creationism in Minnesota. Am Biol Teach. 2005;67:457-66.

Nadelson LS, Sinatra GM. Educational professionals' knowledge and acceptance of evolution. Evol Psychol. 2009;7:490-516.

National Academies of Sciences. http://nationalacademies.org/evolution/ index.html; 2011.

National Association of Biology Teachers. http://www.nabt.org/websites/ institution/index.php?p=110; 2011 .

National Center for Science Education. http://ncse.com/; 2011.

National Science Foundation. Science and technology: public attitudes and understanding. In: Science and engineering indicators, Chapter 7; 2006. pp. 7.1-7.46.

National Science Foundation. http://www.nsf.gov/news/classroom/biology. jsp; 2011.

National Science Teachers Association. Survey indicates science teachers feel pressure to teach nonscientific alternatives to evolution. http:// science.nsta.org/nstaexpress/nstaexpress_2005 03 28 pressrelease. htm; 2005. 
National Science Teachers Association. http://www.nsta.org/publications/ evolution.aspx; 2011

Nehm RH, Schonfeld IS. Does increasing biology teacher knowledge of evolution and the nature of science lead to greater preference for the teaching of evolution in schools? J Sci Teach Educ. 2007;18:699-723.

Padian K. The evolution of creationists in the United States: where are they now, and where are they going? C R Biologies. 2009;332:100-9.

Padian K, Matzke N. Darwin, Dover, 'Intelligent Design' and textbooks. Biochem J. 2009;417:29-42.

Paz-y-Miño-C G, Espinosa A. Assessment of biology majors versus non-majors views on evolution, creationism and intelligent design. Evolution: Education and Outreach. 2009a;2:75-83.

Paz-y-Miño-C G, Espinosa A. Acceptance of evolution increases with student academic level: a comparison between a secular and a religious college. Evolution: Education and Outreach. 2009b;2:655-75.

Paz-y-Miño-C G, Espinosa A. Using horizontal gene transfer and common descent to depict evolution and contrast it with common design. J Eukaryot Microbiol. 2010;57:11-8.

Paz-y-Miño-C G, Espinosa A. New England faculty and college students differ in their views about evolution, creationism, intelligent design, and religiosity. Evolution: Education and Outreach. 2011a;2:323-42.

Paz-y-Miño-C G, Espinosa A. On the theory of evolution versus the concept of evolution: three observations. Evolution: Education and Outreach. 2011b;2:308-12.

Paz-y-Miño-C G, Espinosa A, Bai CY. The jackprot simulation couples mutation rate with natural selection to illustrate how protein evolution is not random. Evolution: Education and Outreach. 2011;3:502-14.

Pennock RT, editor. Intelligent design creationism and its critics. Cambridge, MA: Massachusetts Institute of Technology; 2001.

Petto AJ, Godfrey LR, editors. Scientists confront intelligent design and creationism. New York: W. W. Norton and Company; 2007.

Phy-Olsen A. Evolution, creationism, and intelligent design. Greenwood, Santa Barbara: Historical Guides to Controversial Issues in America; 2010.

Pigliucci M. The evolution-creation wars: why teaching more science just is not enough. McGill Journal of Education. 2007;42:285-306.

Raosoft Inc. Sample size calculator. http://www.raosoft.com/sample size.html; 2011.

Ruse M. The evolution wars: a guide to the debates. New Brunswick: Rutgers University Press; 2001

Scott EC. Evolution vs. creationism: an introduction. 2nd ed. Westport: Greenwood Press; 2009.

Siegel S, Castellan NJ. Nonparametric statistics for the behavioral sciences. Boston: McGraw Hill; 1988.

Smithsonian National Museum of Natural History. http://www.mnh.si. edu/education/; http://humanorigins.si.edu/; 2011.
Stenger VJ. The fallacy of fine-tuning. Amherst: Prometheus Books; 2011.

The Gallup Poll. Majority of Republicans doubt theory of evolution. http://www.gallup.com/poll/27847/Majority-Republicans-DoubtTheory-Evolution.aspx; 2007.

The Gallup Poll. Evolution, creationism, intelligent design. http:/ www.gallup.com/poll/21814/Evolution-Creationism-IntelligentDesign.aspx; 2008.

The Gallup Poll. On Darwin's birthday, only 4 in 10 believe in evolution. http://www.gallup.com/poll/114544/xDarwinBirthday-Believe-Evolution.aspx; 2009.

The Gallup Poll. Four in 10 Americans believe in strict creationism. http://www.gallup.com/poll/145286/Four-Americans-BelieveStrict-Creationism.aspx; 2010.

The Pew Forum on Religion \& Public Life. US religious landscape survey-religious beliefs and practices: diverse and politically relevant. Washington DC. http://religions.pewforum.org/pdf/ report-religious-landscape-study-full.pdf; 2008.

The Pew Global Attitudes Project. World publics welcome global trade but not immigration. Washington DC. http://pewglobal.org/files/ pdf/258.pdf; 2007.

The Pew Research Center for the People \& the Press. Public divided on origins of life: religion a strength and weakness for both parties. Washington DC. http://people-press.org/reports/pdf/254.pdf; 2005.

The Pew Research Center for the People \& the Press. Scientific achievements less prominent than a decade ago: public praises science; scientists fault public, media. Washington DC. http:// people-press.org/reports/pdf/528.pdf; 2009.

The Society for the Study of Evolution. http://www.evolutionsociety. org/resourcesteachers.asp; 2011.

Trani R. I won't teach evolution; it's against my religion. And now for the rest of the story.... Am Biol Teach. 2004;66:419-27.

Understanding Evolution University of California Berkeley. http:// evolution.berkeley.edu/evolibrary/home.php; 2011

University of Arizona. http://biology.arizona.edu/sciconn/Courses forTeachers.htm; 2011.

van Bennekom FC. Customer surveying: a guidebook for service managers. Boston: Customer Service Press; 2002.

Wexler JD. From the classroom to the courtroom: intelligent design and the Constitution. Evolution: Education and Outreach. 2010;3:215-24.

Williams JD. Belief versus acceptance: why do people do not believe in evolution? Bioessays. 2009;31:1255-62.

Young M, Edis T, editors. Why intelligent design fails: a scientific critique of the new creationism. New Brunswick: Rutgers University Press; 2004.

Zaikowski L, Wilkens RT, Fisher K. Science and the concept of evolution: from the big bang to the origin and evolution of life. Evolution: Education and Outreach. 2008;1:65-73. 